\title{
Atmospheric hydrogen peroxide and organic hydroperoxides during PRIDE-PRD'06, China: their concentration, formation mechanism and contribution to secondary aerosols
}

\author{
W. Hua ${ }^{1}$, Z. M. Chen ${ }^{1}$, C. Y. Jie ${ }^{1}$, Y. Kondo ${ }^{2}$, A. Hofzumahaus ${ }^{3}$, N. Takegawa ${ }^{2}$, C. C. Chang ${ }^{4}$, K. D. Lu ${ }^{1,3}$,

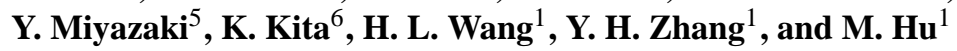 \\ ${ }^{1}$ The State Key Laboratory of Environmental Simulation and Pollution Control, College of Environmental Sciences and \\ Engineering, Peking University, Beijing 100871, China \\ ${ }^{2}$ Research Center for Advanced Science and Technology, Univ. of Tokyo, 4-6-1 Komaba, Meguro, Tokyo 153-8904, Japan \\ ${ }^{3}$ Institut für Chemie und Dynamik der Geosphäre II: Troposphäre, Forschungszentrum Jülich, 52425 Jülich, Germany \\ ${ }^{4}$ Research Center of Environment Changes, Academia Sinica, Nankang, Taipei 115, Taiwan \\ ${ }^{5}$ Institute of Low Temperature Science, Hokkaido University, Kita-19, Nishi-8, Kita-ku, Sapporo 060-0819, Japan \\ ${ }^{6}$ Faculty of Science, Ibaraki University, 2-1-1 Bunkyo, Mito, Ibaraki, 310-8512, Japan
}

Received: 25 April 2008 - Published in Atmos. Chem. Phys. Discuss.: 3 June 2008

Revised: 1 September 2008 - Accepted: 23 September 2008 - Published: 24 November 2008

\begin{abstract}
Atmospheric hydrogen peroxide $\left(\mathrm{H}_{2} \mathrm{O}_{2}\right)$ and organic hydroperoxides were measured from 18 to 30 July in 2006 during the PRIDE-PRD'06 campaign at Backgarden, a rural site located $48 \mathrm{~km}$ north of Guangzhou, a mega-city in southern China. A ground-based instrument was used as a scrubbing coil collector to sample ambient air, followed by on-site analysis by high-performance liquid chromatography (HPLC) coupled with post-column derivatization and fluorescence detection. The $\mathrm{H}_{2} \mathrm{O}_{2}$ mixing ratio over the 13 days ranged from below the detection limit to a maximum of $4.6 \mathrm{ppbv}$, with a mean (and standard deviation) of (1.26 \pm 1.24$)$ ppbv during the daytime (08:00-20:00 LT). Methyl hydroperoxide (MHP), with a maximum of $0.8 \mathrm{ppbv}$ and a mean (and standard deviation) of $(0.28 \pm 0.10) \mathrm{ppbv}$ during the daytime, was the dominant organic hydroperoxide. Other organic peroxides, including bis-hydroxymethyl hydroperoxide (BHMP), peroxyacetic acid (PAA), hydroxymethyl hydroperoxide (HMHP), 1-hydroxy-ethyl hydroperoxide (1-HEHP) and ethyl hydroperoxide (EHP), were detected occasionally. The concentration of $\mathrm{H}_{2} \mathrm{O}_{2}$ exhibited a pronounced diurnal variation on sunny days, with a peak mixing ratio in the afternoon (12:00-18:00 LT), but lacked an explicit diurnal cycle on cloudy days. Sometimes a second peak mixing ratio of $\mathrm{H}_{2} \mathrm{O}_{2}$ was observed during the evening, suggesting that $\mathrm{H}_{2} \mathrm{O}_{2}$ was produced by the ozonolysis of
\end{abstract}

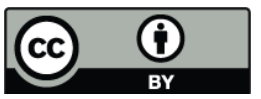

Correspondence to: Z. M. Chen (zmchen@pku.edu.cn) alkenes. The diurnal variation profile of MHP was, in general, consistent with that of $\mathrm{H}_{2} \mathrm{O}_{2}$. The estimation indicated that in the morning the $\mathrm{H}_{2} \mathrm{O}_{2}$ detected was formed mostly through local photochemical activity, with the rest probably attributable to vertical transport. It is notable that relatively high levels of $\mathrm{H}_{2} \mathrm{O}_{2}$ and MHP were found in polluted air. The unexpectedly high level of $\mathrm{HO}_{2}$ radicals detected in this region can account for the production of hydroperoxides, while the moderate level of $\mathrm{NO}_{\mathrm{x}}$ suppressed the formation of hydroperoxides. High concentrations of hydroperoxides were detected in samples of rainwater collected in a heavy shower on 25 July when a typhoon passed through, indicating that a considerable mixing ratio of hydroperoxides, particularly MHP, resided above the boundary layer, which might be transported on a regional scale and further influence the redistribution of $\mathrm{HO}_{\mathrm{x}}$ and $\mathrm{RO}_{\mathrm{x}}$ radicals. It was found that hydroperoxides, in particular $\mathrm{H}_{2} \mathrm{O}_{2}$, play an important role in the formation of secondary sulfate in the aerosol phase, where the heterogeneous reaction might contribute substantially. A negative correlation between hydroperoxides and water-soluble organic compounds (WSOC), a considerable fraction of the secondary organic aerosol (SOA), was observed, possibly providing field evidence for the importance of hydroperoxides in the formation of SOA found in previous laboratory studies. We suggest that hydroperoxides act as an important link between sulfate and organic aerosols, which needs further study and should be considered in current atmospheric models. 


\section{Introduction}

A series of hydroperoxides, including hydrogen peroxide $\left(\mathrm{H}_{2} \mathrm{O}_{2}\right)$ and organic hydroperoxides $(\mathrm{ROOH})$, such as methylhydroperoxide (MHP, $\mathrm{CH}_{3} \mathrm{OOH}$ ), hydroxymethyl hydroperoxide (HMHP, $\mathrm{HOCH}_{2} \mathrm{OOH}$ ), 1-hydroxy-ethyl hydroperoxide (1-HEHP, $\left.\mathrm{CH}_{3} \mathrm{CH}(\mathrm{OH}) \mathrm{OOH}\right)$, peroxyacetic acid (PAA, $\mathrm{CH}_{3} \mathrm{C}(\mathrm{O}) \mathrm{OOH}$ ) and ethylhydroperoxide (EHP, $\mathrm{CH}_{3} \mathrm{CH}_{2} \mathrm{OOH}$ ), have been measured in the atmosphere since the measurement of organic hydroperoxides was pioneered in the 1980s by Hellpointner and Gäb (1989). These reactive species play significant roles in atmospheric processes, such as acid precipitation, cycling of $\mathrm{HO}_{\mathrm{x}}$ radicals, and formation of secondary organic aerosol (SOA). $\mathrm{H}_{2} \mathrm{O}_{2}$ is considered to be the most important oxidant for the conversion of S (IV) to sulfuric acid and secondary sulfate in cloud, fog and rain water at $\mathrm{pH}<5$, thus contributing significantly to the acidification of clouds and rain (Penkett et al., 1979; Calvert et al., 1985; Fung et al., 1991; Pena et al., 2001). Organic peroxides such as MHP, HMHP, and PAA are able to oxidize $\mathrm{SO}_{2}$, but only when $\mathrm{H}_{2} \mathrm{O}_{2}$ is limited (Lind et al., 1987; Zhou and Lee, 1992). For instance, HMHP is much more soluble than $\mathrm{H}_{2} \mathrm{O}_{2}\left(\mathrm{H}_{\mathrm{H}_{2} \mathrm{O}_{2}}=7.7 \times 10^{4} \mathrm{Matm}^{-1}\right.$ and $\mathrm{H}_{\mathrm{HMHP}}=1.7 \times 10^{6} \mathrm{M} \mathrm{atm}^{-1}$ at $298 \mathrm{~K}$, Sander et al., 2003) and can decompose rapidly into $\mathrm{H}_{2} \mathrm{O}_{2}$ and $\mathrm{HCHO}$ in the aqueous phase when $\mathrm{pH}>5.0$ (O'Sullivan et al., 1996; Chen et al., 2008). In addition, $\mathrm{H}_{2} \mathrm{O}_{2}$ and $\mathrm{MHP}$ can serve as temporary reservoirs of odd-hydrogen radicals $\left(\mathrm{OH}, \mathrm{HO}_{2}, \mathrm{CH}_{3} \mathrm{O}_{2}\right)$ in the troposphere, because their photolysis and other reactions will lead to the regeneration of $\mathrm{OH}$ radicals, and are intimately involved in the production of odd-oxygen (e.g. O, $\mathrm{O}_{3}$ ) (Madronich and Calvert, 1990; Lightfoot et al., 1992; Reeves and Penkett, 2003). For example, MHP, which is the most abundant organic hydroperoxide in the atmosphere, and has an atmospheric lifetime of 2-3 days and a low level of solubility in water (Cohan et al., 1999; Wang and Chen, 2006), can be transported to the upper troposphere at a regional scale without scavenging under deep convection conditions. As a result, this transportation probably leads to the redistribution of $\mathrm{OH}$ radicals in different regions and different altitudes (Jaeglé et al., 1997; Wennberg et al., 1998; Cohan et al., 1999; Mari et al., 2000; Ravetta et al., 2001), and $\mathrm{H}_{2} \mathrm{O}_{2}$ and organic hydroperoxides can be used as indicators of the oxidizing capacity of the troposphere (Thompson, 1992). Tropospheric aerosols play an important role in the Earth's atmosphere and in the climate system. Aerosols scatter and absorb solar radiation (direct effect) (Andreae and Crutzen, 1997), change cloud characteristics in many ways (indirect effect) (e.g. Navakov and Penner, 1993; Lohmann and Feichter, 2005), and facilitate heterogeneous and multiphase chemistry (Ravishankara, 1997). Increasing attention is being paid to the organic matter that represents a substantial fraction of tropospheric aerosols (Andreae and Crutzen, 1997). Recently, several laboratory studies have revealed that secondary organic aerosol (SOA) can be formed from isoprene and its gas-phase oxidation products through acidcatalyzed heterogeneous oxidation with hydrogen peroxide, a remarkably close analogy with atmospheric secondary sulfate formation (Claeys et al., 2004; Böge et al., 2006; Kroll et al., 2006).

No significant direct emission of $\mathrm{H}_{2} \mathrm{O}_{2}$ or organic hydroperoxides from natural or anthropogenic sources has been found, and it is believed that the majority of the $\mathrm{H}_{2} \mathrm{O}_{2}$ and $\mathrm{ROOH}$ in the gas phase are formed via the bimolecular and termolecular recombination of peroxy $\left(\mathrm{HO}_{2}\right.$ and $\left.\mathrm{RO}_{2}\right)$ radicals during the daytime. The only known mechanism for the formation of peroxides in the absence of light is the ozonolysis reaction of alkenes (Gäb et al., 1985; Becker et al., 1990, 1993; Valverde-Canossa et al., 2004), which is discussed in detail in Sect. 3.4. This reaction is the main source of the 1hydroxyalkylhydroperoxides (1-HAHP) and a source of $\mathrm{OH}$ radicals (Atkinson and Aschmann, 1993; Paulson and Orlando, 1996).

Formation of $\mathrm{HO}_{2}$ radicals is predominantly through the photo-oxidation of carbon monoxide (CO) and volatile organic compounds (VOC) by the $\mathrm{OH}$ radical (described in detail by Lightfoot et al., 1992). The second significant part of $\mathrm{HO}_{2}$ is formed during the degradation of $\mathrm{HCHO}$ and other aldehydes by photolysis or by reaction with $\mathrm{OH}$ radicals (Buffalini et al., 1972; Su et al., 1979). Furthermore, the ozonolysis of alkenes, the decomposition of peroxy acetyl nitrate (PAN), and the photodegradation of aromatic hydrocarbons will provide a source of $\mathrm{HO}_{2}$ (Finlayson-Pitts and Pitts, 1986; Seuwen and Warneck, 1995). Alkylperoxy radicals $\left(\mathrm{RO}_{2}\right)$ are produced by the reaction of $\mathrm{OH}$ radicals with alkanes, e.g. $\mathrm{CH}_{4}$, in the presence of oxygen, and by the decomposition of alkyl-substituted, excited Criegee biradicals (Atkinson, 1994; Hatakeyama and Akimoto, 1994; Gäb et al., 1995).

The sinks for gaseous $\mathrm{H}_{2} \mathrm{O}_{2}$ and organic peroxides can be classified according to different processes, including washout through fog droplets and adsorption on watercovered aerosols or other wet surfaces; dry deposition; photolysis; and reaction with $\mathrm{OH}$ radicals. Although the importance of the individual processes might differ with regard to the water solubility of the organic peroxides (Gunz and Hoffmann, 1990; Watkins et al., 1995a, b), the washout and adsorption processes on wet surfaces are expected to be dominant.

Field, laboratory and modeling studies have all indicated that the generation and behavior of gas-phase $\mathrm{H}_{2} \mathrm{O}_{2}$ and organic ROOH are affected by the levels of chemical components such as $\mathrm{NO}_{\mathrm{x}}, \mathrm{CO}, \mathrm{CH}_{4}$, and VOC. Additionally, meteorological parameters, including solar radiation, relative humidity, temperature, and pressure are of great importance in controlling the production and the loss of hydroperoxides (Lee et al., 2000).

Over the past two decades, the distribution and roles of $\mathrm{H}_{2} \mathrm{O}_{2}$ and $\mathrm{CH}_{3} \mathrm{OOH}$ in the atmosphere have been investigated by various methods on land, onboard ship, and aboard 
aircraft (Hellpointner and Gäb, 1989; Hewitt and Kok, 1991; Das and Aneja, 1994; Fels and Junkermann, 1994; Watkins et al., 1995a, b; Staffelbach et al., 1996; Heikes et al., 1996; Jackson and Hewitt, 1996; Sauer et al., 1997, 2001; Lee et al., 1993, 1995, 1997, 1998, 2000, 2008; Morgan and Jackson, 2002; Grossmann et al., 2003; François et al., 2005; Walker et al., 2006; Kim et al., 2007). Although numerous field measurements of $\mathrm{H}_{2} \mathrm{O}_{2}$ and organic peroxides have been made, most of them were done at $25^{\circ}-55^{\circ} \mathrm{N}$, including North America, Brazil, Europe, Greenland, South Africa, and the Atlantic and the northwestern and central tropical Pacific (Lee et al., 2000). To our knowledge, data for hydroperoxides on land are not available for the East Asia low latitude region, where the atmospheric chemistry may be significantly distinguished from other regions on the earth. Accompanying rapid industrialization, East Asia has increasing amounts of $\mathrm{O}_{3}$ precursor trace gases (carbon monoxide, nitrogen oxides, and hydrocarbons) released by industrial, agricultural and population growth. The Pearl River Delta (PRD) region, extending from the Hong Kong metropolitan area to the northwest, has been the most economically dynamic region of mainland China over the last two decades. The high levels of $\mathrm{NO}_{\mathrm{x}}, \mathrm{SO}_{2}$, ozone and $\mathrm{PM}_{2.5}$ observed in the PRD region over the past decade are believed to be associated with the rapid economic development (Zhang et al., 1998; Wang et al., 2003; Li et al., 2005). As intermediate photochemical byproducts, hydroperoxides can be used to test predictions by photochemical models by comparison with observed data (Jacob et al., 1996). Therefore, field studies of peroxides are needed urgently to provide valuable data for investigating the photochemical mechanisms in this region and to be included in photochemical models.

We present a novel dataset for speciated hydroperoxides measured at a rural site in PRD that has high mixing ratios of VOC and CO. The objectives of this study were to investigate the impact of chemical and physical processes on the mixing ratio of $\mathrm{H}_{2} \mathrm{O}_{2}$ and organic peroxides, to provide new field evidence of the existence of high mixing ratios of hydroperoxides above the planetary boundary layer (PBL), to examine the contribution of hydroperoxides to the formation of secondary sulfate and SOA, and ultimately to assess the value of hydroperoxide measurements for better understanding the mechanisms of secondary photochemical pollutions and to aid the development of more robust models.

\section{Experimental}

\subsection{Measurement site}

The measurements were carried out at Backgarden $\left(23.548^{\circ} \mathrm{N} 113.066^{\circ} \mathrm{E}\right)$, a super-site for the PRIDEPRD'06 (Program of Regional Integrated Experiments of Pearl River Delta Region) Air Quality Monitoring Campaign that took place from 3 to 30 July 2006. Backgarden is a rural site, surrounded by $20 \mathrm{~km}^{2}$ of forest and $2.7 \mathrm{~km}^{2}$ of lake, located north of the central PRD and about $60 \mathrm{~km}$ northwest of the mega-city Guangzhou in southeast China, which is the capital city of Guangdong Province. The increase in industry and population impacts the air quality of Guangzhou. Guangzhou is undergoing a complex air pollution composition due to the mixture of coal burning and vehicle emissions. Backgarden is a much less populated area at the outskirts of the densely populated center of the PRD and can be treated as a regional background site. Backgarden does not have significant local vehicle emission, while the biomass burning in the afternoon and cable burning in the evening might be a source of local emission. The Backgarden site experiences a typical sub-tropical climate and is usually influenced by the monsoon circulation in the July. During the period of hydroperoxides measurement, the observation site was mainly influenced by the western pacific subtropical high and typhoon. When controlled by the western pacific subtropical high pressure from 19 to 23 July, the days were sunny, and the dominant wind direction at Backgarden was southerly. When influenced by typhoon from 24 to 25 July, northerly winds prevailed at the observation site. During the last days of the campaign from 26 to 30 July, the local weather conditions were cloudy and rainy and the sampled air masses came mainly from the south/southeast. The average meteorological values (arithmetic mean \pm standard deviation) for the campaign were: $29.5 \pm 3.4^{\circ} \mathrm{C}$ ambient temperature, $76.2 \pm 14.4 \%$ ambient relative humidity, $1001 \pm 4 \mathrm{hPa}$ ambient pressure, and $1.9 \pm 1.2 \mathrm{~m} / \mathrm{s}$ local wind speed. The details of meteorological values are shown in Fig. 4 in Sect. 3.1. The primary pollutants including $\mathrm{NO}_{\mathrm{x}}, \mathrm{CO}$, and $\mathrm{SO}_{2}$ influenced the hydroperoxides level significantly during the campaign. Their concentrations kept relatively low in the daytime, but were elevated at night, particularly under southeasterly from 20 to 22 July. In addition to the measurement of peroxides, all major trace gases $\left(\mathrm{NO}_{\mathrm{x}}, \mathrm{NO}_{\mathrm{y}}, \mathrm{PAN}, \mathrm{SO}_{2}\right.$, $\mathrm{CO}, \mathrm{O}_{3}$, biogenic/anthropogenic VOC, etc.), aerosols (mass concentration, number concentration, chemical compositions), free radicals $\left(\mathrm{OH}, \mathrm{HO}_{2}, \mathrm{RO}_{2}\right)$ and meteorological parameters (temperature, wind direction, wind speed and relative humidity, pressure, rainfall) were monitored at this site by a number of groups.

\subsection{Measurement method for hydroperoxides}

\subsubsection{Measurement method}

A three-story hotel building, which located next to a $2.7 \mathrm{~km}^{2}$ reservoir in a rural resort surrounded by a large area of farmland and forest, was used exclusively to house the campaign measurement team. This building stood with almost no other buildings within $300 \mathrm{~m}$ radius area. The instrument for determining hydroperoxides was located in an air conditioned room on the top floor, and the sampling inlet was mounted 
on the rooftop. The space over the rooftop was very open to surroundings, thus made it possible to collect well mixed and representative air samples. Ambient air was drawn by a vacuum pump through a $6 \mathrm{~m}$ Teflon tube (1/4 inch O.D.) extending $1.5 \mathrm{~m}$ above the rooftop of the building, so that the air samples were taken about $12 \mathrm{~m}$ above the ground. The air flow rate was $2.7 \mathrm{slm}$ (standard liters per minute), controlled by a mass flow controller. The air residence time in the inlet tubing was less than $2 \mathrm{~s}$, and there was no filter in the inlet system. The air samples were collected in a thermostatically controlled glass coil collector, at a temperature of around $10^{\circ} \mathrm{C}$. The stripping solution, acidified $18 \mathrm{M} \Omega$ water $\left(\mathrm{H}_{3} \mathrm{PO}_{4}, \mathrm{pH} 3.5\right)$ was delivered into the collector by an HPLC pump (Agilent 1050) at a rate of $0.2 \mathrm{~mL} \mathrm{~min}^{-1}$ to collect hydroperoxides. The coil itself is about $30 \mathrm{~cm}$ long and the tube has an effective length of $\sim 100 \mathrm{~cm}$ and $2 \mathrm{~mm}$ I.D. (Sauer et al., 1999). The scrubbing coil is similar to that used in earlier studies (Lazrus et al., 1986; Neeb et al., 1997; Sauer et al., 1999, 2001; Grossmann et al., 2003; François et al., 2005).

The collection efficiency of the coil was determined as follows. First, vapor containing $\mathrm{H}_{2} \mathrm{O}_{2}$ and MHP was generated by a saturated vapor generator (Lind and Kok, 1986; Li et al., 2004). The air stream flowed over the thermostatically controlled quartz fiber membrane $\left(15 \pm 0.2^{\circ} \mathrm{C}\right)$, which was saturated by the standard solution, at a rate of $0.2 \mathrm{slm}$. Lind and Kok (1986) demonstrated that the air stream rate should be less than $1 \mathrm{slm}$ in order to ensure Henry's Law equilibrium. Second, additional pure air $(2.5 \mathrm{slm})$ was added to the generated vapor of hydroperoxides via a three-port valve. Then the mixed air stream of standard gas of $\mathrm{H}_{2} \mathrm{O}_{2}$ and MHP was drawn into the scrubbing coil collector at a total flow rate of $2.7 \mathrm{slm}$ under the conditions used for atmospheric measurement. Using a solution containing $2.4 \times 10^{-3} \mathrm{M} \mathrm{H}_{2} \mathrm{O}_{2}$ and $3.5 \times 10^{-6} \mathrm{MMHP}$, the levels of gaseous hydroperoxides in the standard gas were calculated to be $\sim 1 \mathrm{ppbv}$ for $\mathrm{H}_{2} \mathrm{O}_{2}$ and $\sim 0.5 \mathrm{ppbv}$ for MHP. The concentration of this standard gas was also determined using a Horibe tube in a cold trap of ethanol/liquid nitrogen at $\sim-90^{\circ} \mathrm{C}$ (Hewitt and Kok, 1991), for collection and for HPLC analysis (described below). The standard gas concentration determined by the cold trap method was consistent with the concentration calculated by Henry's Law $\left(\mathrm{H}_{\mathrm{H}_{2} \mathrm{O}_{2}}=1.8 \times 10^{5} \mathrm{Matm}^{-1}\right.$ and $\mathrm{H}_{\mathrm{MHP}}=5.7 \times 10^{2} \mathrm{M} \mathrm{atm}^{-1}$ at $15^{\circ} \mathrm{C}$, Sander et al., 2003). After collection, the stripping solution was analyzed by HPLC. The collection efficiency of the coil was estimated using the ratio of the measured concentration and the known concentration of the standard gas, with $\geq 98 \%$ for $\mathrm{H}_{2} \mathrm{O}_{2}$ and $\sim 85 \%$ for MHP at $10^{\circ} \mathrm{C}$. These values are in agreement with those of previous studies (Sauer et al., 1997, 2001; François et al., 2005). The heterogeneous decomposition of $\mathrm{H}_{2} \mathrm{O}_{2}$ and MHP in the coil was negligible under the experimental conditions, as proved by previous studies (Sauer et al., 1996, 2001).

After the sampled air passed through the coil collector, the stripping solution was removed from the separator using a peristaltic pump and immediately injected manually into the HPLC valve, from which $100 \mu \mathrm{L}$ was analyzed by HPLC. Because of the lack of an auto-sampler for the HPLC analysis, the sample analysis was performed in a quasi-continuous mode with an interval of 20-60 min, and thus only a few samples were measured at night and in the early morning. Several rain samples were collected during a heavy shower using a glass funnel (diameter $10 \mathrm{~cm}$ ) connected to a $5 \mathrm{~m}$ Teflon tube (1/8-inch O.D.), from the end of which the rain samples were collected and injected immediately into the HPLC column.

The HPLC was done with post-column derivatization using $p$-hydroxyphenylacetic acid (POPHA) and fluorescence detection. The basis of this method is to quantify the fluorescent dimer produced by the stoichiometric reaction of POPHA and hydroperoxides through catalysis (Gäb et al., 1985; Hellpointner and Gäb, 1989; Kurth et al., 1991; Lee et al., 1995; Sauer et al., 1996, 1997, 1999, 2001; Grossmann et al., 2003; François et al., 2005; Xu and Chen, 2005; Walker et al., 2006). The catalyst used in this study was Hemin (Xu and Chen, 2005; Chen et al., 2008). The mobile phase, controlled by the HPLC pump (Agilent 1200) at a constant rate of $0.5 \mathrm{~mL} \mathrm{~min}^{-1}$, was a $\mathrm{H}_{3} \mathrm{PO}_{4}$ solution at pH 3.5 (Sigma-Aldrich, 85\% for HPLC). The hydroperoxides were separated in a $5 \mu \mathrm{m}$ reversed-phase $\mathrm{C}_{18}$ HPLC column $(4.6 \mathrm{~mm} \times 250 \mathrm{~mm}$, ZORBAX, SB-Aq, Agilent), which was cooled to $\sim 2^{\circ} \mathrm{C}$ to stabilize the hydroperoxides. After separation, the eluate was introduced into a $3 \mathrm{~m}$ Teflon coil at $42( \pm 1)^{\circ} \mathrm{C}$ for post-column derivatization. The fluorescent reagent, $8 \times 10^{-6} \mathrm{M}$ Hemin (Fluka) and $8 \times 10^{-5} \mathrm{M}$ POPHA (ACROS ORGNICS), was adjusted to pH 10-11 with $\mathrm{NH}_{4} \mathrm{Cl} / \mathrm{NH}_{4} \mathrm{OH}$ buffer solution. The flow rate of the fluorescent reagent was $0.2 \mathrm{~mL} \mathrm{~min}^{-1}$. The fluorescence signal of the biphenyl derivative formed in the derivatization reaction was determined at wavelengths of $\lambda_{\mathrm{Ex}}=315 \mathrm{~nm}$ and $\lambda_{\mathrm{Em}}=400 \mathrm{~nm}$ using a fluorescence detector (Agilent 1200).

Sample blanks were determined at least twice daily by measuring the stripping solution at the stripping solution outlet of the coil after stopping the air vacuum pump for 10 min. $\mathrm{H}_{2} \mathrm{O}_{2}$ was occasionally found in the blanks but only in trace amounts. When the pure synthetic air was introduced to the sampling inlet instead of the ambient air, our instrument did not detected any peroxides in the samples, indicating that the artefact production of peroxides within the sampling set-up was negligible. Multipoint calibration of the HPLC for analysis of hydroperoxides was performed weekly with $\mathrm{H}_{2} \mathrm{O}_{2}$, MHP and EHP standard solution in the range of $1 \times 10^{-8} \sim 1 \times 10^{-5} \mathrm{M}$, and single-point calibration was done three times a day with a mixing standard solution of $\mathrm{H}_{2} \mathrm{O}_{2}$, MHP and EHP. Organic hydroperoxides were identified by comparing the retention times with those of reference substances. The HPLC chromatogram shown in Fig. 1 illustrates the separation and retention times of a mixture of hydroperoxides during the measurements. The detection limit of $\mathrm{H}_{2} \mathrm{O}_{2}$, defined as three times the standard deviation of the 


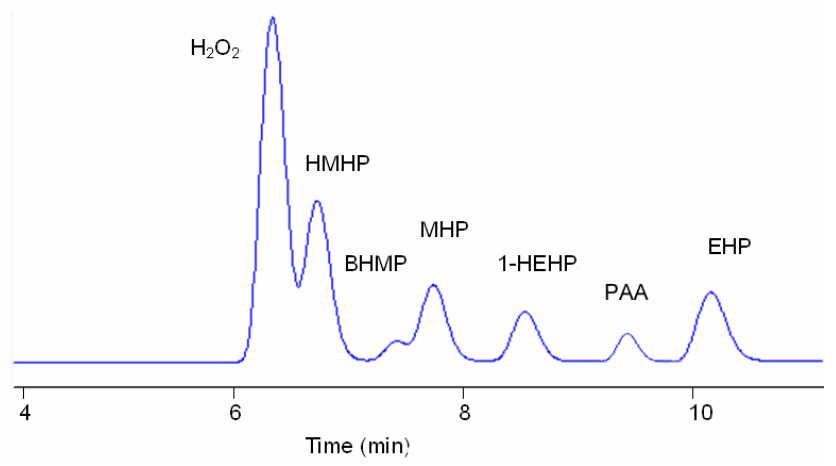

Fig. 1. HPLC chromatogram of a mixture of hydroperoxides showing separation and retention times.

analytical blanks of Milli-Q water, was $0.012 \mu \mathrm{Mol} \mathrm{L}^{-1}$ using a $100 \mu \mathrm{L}$ sampling loop. The detection limit of MHP, based on three times the standard deviation of the MHP standard solution $\left(7.0 \times 10^{-7} \mathrm{M}\right)$, was $0.021 \mu \mathrm{Mol} \mathrm{L}^{-1}$. These corresponded to the detection limits of about $20 \mathrm{pptv}$ for $\mathrm{H}_{2} \mathrm{O}_{2}$ and 35 pptv for MHP in the gas phase under the sampling conditions mentioned above.

$\mathrm{H}_{2} \mathrm{O}_{2}$ was purchased from Sigma-Aldrich (35\%), and fresh solutions were prepared by serial dilution of the $0.35 \%$ stock solution. Methyl hydroperoxide and ethyl hydroperoxide were synthesized from $\mathrm{H}_{2} \mathrm{O}_{2}$ and dimethyl sufate or diethyl sulfate as described (Rieche and Hitz, 1929; Kok et al., 1995; Lee, et al., 1995). The purities of the synthesized MHP and EHP were proved to be higher than $97 \%$ using infrared spectrometry. The hydroxymethy hydroperoxide (HMHP), 1-hydroxy-ethyl hydroperoxide (1-HEHP) were synthesized from aqueous $\mathrm{H}_{2} \mathrm{O}_{2}$ and formaldehyde or acetaldehyde (Rieche and Meister, 1935; Zhou and Lee, 1992; Lee et al., 1995). The concentrations of stock solutions and standard solutions were determined using $\mathrm{KMnO}_{4}$ and $\mathrm{KI} / \mathrm{Na}_{2} \mathrm{~S}_{2} \mathrm{O}_{3} /$ starch every two weeks (Johnson and Siddigu, 1970; Mair and Hall, 1970). All reagents and standard solution were prepared with $18 \mathrm{M} \Omega$ Milli-Q water (Millipore), and were stored at $4^{\circ} \mathrm{C}$ in a refrigerator.

\subsubsection{Estimation of $\mathrm{SO}_{2}$ interference}

The $\mathrm{SO}_{2}$ interference on the peroxides measurement should be clarified before interpreting the observations. We estimated this interference by two methods as following.

One estimation was made by a kinectics calculation. At $10^{\circ} \mathrm{C}$ temperature adopted in our sample collection, the Henry's Law constants of $\mathrm{H}_{2} \mathrm{O}_{2}$ and $\mathrm{SO}_{2}$ are $2.85 \times 10^{5} \mathrm{M} \mathrm{atm}^{-1}$ and $2.32 \mathrm{M} \mathrm{atm}^{-1}$ respectively (Sander et al., 2003). The total amount of dissolved S(IV) always exceeds that predicted by Henry's $\mathrm{Law}$ for $\mathrm{SO}_{2}$ alone, so we calculate the effective Henry's Law constant of $\mathrm{SO}_{2}$ by the expression given in textbook (Seinfeld and Pandis, 1998), and obtain a value of $98 \mathrm{M} \mathrm{atm}^{-1}$ at $\mathrm{pH} 3.5$. Assuming the mixing ratios of $\mathrm{H}_{2} \mathrm{O}_{2}$ and $\mathrm{SO}_{2}$ were $1 \mathrm{ppbv}$ and $10 \mathrm{ppbv}$ respectively in the sampled air, and then the equilibrium concentrations of $\mathrm{H}_{2} \mathrm{O}_{2}$ and $\mathrm{SO}_{2}$ in collection solution at $\mathrm{pH} 3.5$ are estimated to be $285 \mu \mathrm{M}$ and $1 \mu \mathrm{M}$ respectively in solution, on the basis of Henry's Law. Then, the reaction rate of the dissolved $\mathrm{H}_{2} \mathrm{O}_{2}$ and $\mathrm{S}$ (IV) can be calculated to be $\sim 6.6 \mu \mathrm{M} \mathrm{s}^{-1}$ at $\mathrm{pH} 3.5$. In the glass coil collector used in this study, the contact time of the sampled air with the collection solution was less than $10 \mathrm{~s}$. After this time, the hydroperoxides-containing collection solution was separated from the sampled air, and was rapidly delivered into the HPLC system. This means that the $\mathrm{SO}_{2}$ in sampled air can destroy $\mathrm{H}_{2} \mathrm{O}_{2}$ and influence $\mathrm{H}_{2} \mathrm{O}_{2}$ measurement only within this $10 \mathrm{~s}$. On the basis of above calculation, we can give an estimation that, when 1 ppbv $\mathrm{H}_{2} \mathrm{O}_{2}$ and 10 ppbv $\mathrm{SO}_{2}$ exists in the sampled air, about $66 \mu \mathrm{M}$ of $285 \mu \mathrm{M} \mathrm{H}_{2} \mathrm{O}_{2}$ equilibrated in the collected solution will be destroyed by $\mathrm{SO}_{2}$ during collection, indicating that the mixing ratio of $\mathrm{H}_{2} \mathrm{O}_{2}$ will be underestimated by $23 \%$. More details regarding the interference of $\mathrm{SO}_{2}$ in $\mathrm{H}_{2} \mathrm{O}_{2}$ measurement are as follows: when the $\mathrm{SO}_{2}$ presents in sampled air with 2, 5, 10, 15, 20 and $30 \mathrm{ppbv}$ respectively, the losses of $\mathrm{H}_{2} \mathrm{O}_{2}$ are estimated to be $5 \%, 12 \%$, $23 \%, 35 \%, 46 \%, 70 \%$, respectively.

Another estimation was made by a laboratory experiment. We studied the $\mathrm{SO}_{2}$ interference using the Horibe tube, which was described above. The Horibe tube was added with $1 \mathrm{ml}$ mixing standard solution containing $10^{-6} \mathrm{M} \mathrm{H}_{2} \mathrm{O}_{2}$, MHP and EHP, comparable to their concentrations in the atmosphere, following by cooling it at $\sim-90^{\circ} \mathrm{C}$ and then introducing the $\mathrm{SO}_{2}$-containing air flow. After the $\mathrm{SO}_{2}$ containing air flow passed it for $30 \mathrm{~min}$ at the rate of $2.7 \mathrm{slm}$, the Horibe tube was taken out from the cold trap, and $2 \mathrm{ml}$ of $10^{-3} \mathrm{M} \mathrm{H}_{3} \mathrm{PO}_{4}$ solution was added quickly to wash the inside of the Horibe tube, and then the washed sample solution was quickly analyzed by HPLC. In this procedure, the contact time of the hydroperoxides with the $\mathrm{S}(\mathrm{IV})$ in the solution was $\sim 5 \mathrm{~min}$ at $\sim 10^{\circ} \mathrm{C}$. We found that the losses of $\mathrm{H}_{2} \mathrm{O}_{2}$ are $\sim 10 \%, \sim 30 \%$ and $\sim 50 \%$ respectively when the $\mathrm{SO}_{2}$ concentrations are $10 \mathrm{ppbv}, 25 \mathrm{ppbv}$ and $50 \mathrm{ppbv}$ respectively. The losses of the organic hydroperoxides were lower than that of $\mathrm{H}_{2} \mathrm{O}_{2}$.

In summary, we suggest that the interference of $\mathrm{SO}_{2}$ in the peroxides measurement will not be significant under a $15 \mathrm{ppbv}$ level of $\mathrm{SO}_{2}$, under our observation conditions.

\subsection{Measurement methods for other trace gases}

$\mathrm{HO}_{2}$ radicals were measured at the Backgarden site by a laser-induced fluorescence instrument, operated by Forschungszentrum Juelich (FZJ). Briefly, ambient air is sampled continuously into a low-pressure detection chamber, where $\mathrm{HO}_{2}$ is chemically converted to $\mathrm{OH}$ by reaction with added NO. The resulting $\mathrm{OH}$ is then detected by laser excited fluorescence at a wavelength of $308 \mathrm{~nm}$. The instrument is calibrated by using the quantitative photolysis of water 
vapour in synthetic air at $185 \mathrm{~nm}$ as a radical source. The accuracy of the measurements is estimated to be $20 \%$ for this campaign. Details of the instrument and its calibration can be found in Holland et al. (2003).

Semi-continuous measurements of WSOC were made by University of Tokyo (UT) using a particle-into-liquid sampler (PILS) followed by online quantification of TOC every 6 min using a total organic carbon (TOC) analyzer. Ambient aerosol was sampled at a flow rate of $16.7 \mathrm{~L} / \mathrm{min}$ by the PILS, which used a steam saturator to grow the aerosol to sizes that can be collected by inertial impaction. The carbonaceous compounds in the liquid sample were then quantified online with the TOC analyzer. Details of the instrument can be found in Miyazaki et al. (2006).

The sulfate measurements were performed by the Aerodyne Aerosol Mass Spectrometer (AMS), operated by University of Tokyo (UT). The AMS can measure size-resolved chemical composition of ambient non-refractory (vaporized at $600^{\circ} \mathrm{C}$ under high vacuum) submicron aerosol for an integration time of $10 \mathrm{~min}$. The AMS consists of a particle sampling inlet with cutoff size $1.0 \mu \mathrm{m}$, a particle time-of-flight (PTOF) chamber, and a vaporizer/ionizer that is interfaced to a quadrupole mass spectrometer (QMS). Details of the instrument can be found in Takegawa et al. (2005).

The continuous measurements of $47 \quad \mathrm{C}_{2}-\mathrm{C}_{12}$ VOC species, including alkanes, alkenes and aromatic hydrocarbons, were performed hourly using an automated online Gas Chromatography-Flame Ionization Detector (GC-FID) system from the Research Center for Environmental Changes (RCEC), Academia Sinica of Taiwan. The detection limit for the measured VOC species ranged from 0.002 to $0.098 \mathrm{ppbv}$. The calibrations of the instrument were carried out before and after the campaign using a standard gas prepared by the gravimetric method (Spectra gases, Branchburg, NJ, USA), which contained 50 target species with mixing ratios of 3$15 \mathrm{ppbv}$. It was found that the precisions for the measured VOC species were usually better than $2 \%$. Details of the GC-FID system and analytical procedures employed in this study can be found in Wang et al. (2004).

The $\mathrm{SO}_{2}$ was determined by Peking University (PKU) using $\mathrm{SO}_{2}$ Analyzer (Thermo, Model 43C) with a time resolution of $1 \mathrm{~min}$. The data of $\mathrm{CO}, \mathrm{O}_{3}$ and $\mathrm{NO}_{\mathrm{x}}$ used in this study were obtained from the combined data set of PKU, UT and FZJ. During the period we discuss in this study, the $\mathrm{CO}$ was measured by a $\mathrm{CO}$ Analyzer (Thermo, Model 48C) with a time resolution of 1 min, operated by PKU, and a non-dispersive infrared absorption (NDIR) instrument with an integration time of $1 \mathrm{~min}$ (Model 48, TECO), operated by UT (details of the instrument described by Takegawa et al., 2006), and the $\mathrm{O}_{3}$ was mainly measured by a $\mathrm{O}_{3}$ Analyzer (Thermo, Model 49C) with a time resolution of $1 \mathrm{~min}$ operated by $\mathrm{PKU} . \mathrm{NO}_{\mathrm{x}}$ and $\mathrm{NO}_{\mathrm{y}}$ were measured using a NO$\mathrm{O}_{3}$ chemiluminescence detector combined with a photolytic converter and a gold tube catalytic converter (Takegawa et al., 2006). $\mathrm{NO}_{\mathrm{y}}$ compounds were catalytically converted to $\mathrm{NO}$ on the surface of a gold tube heated at $300^{\circ} \mathrm{C}$. The photolytic converter system used for the $\mathrm{NO}_{2}$ measurement was manufactured by the Droplet Measurement Technologies, Inc., USA.

\section{Results and discussion}

\subsection{General observations}

A total of 354 air samples were characterized using the scrubbing coil collector from the 19th to the 30th of July 2006 during the PRIDE-PRD'06 campaign. The major hydroperoxide present in the air samples collected at the Backgarden site was $\mathrm{H}_{2} \mathrm{O}_{2}$ with mixing ratios between below the detection limit (20 pptv) and $4.6 \mathrm{ppbv}$, and MHP with mixing ratios between $<35$ pptv (d.l.) and 0.8 ppbv. The organic peroxides BHMP and PAA were often detected, and HMHP, 1-HEHP and EHP were occasionally detected, but all these species were present at only several-decade pptv level under these experimental conditions. In order to calculate the mean of the observed mixing ratios, any value below the detection limit was treated as zero. With regard to all samples, the mean (and standard deviation) mixing ratios during the daytime (08:00-20:00 LT) were $1.26 \pm 1.24 \mathrm{ppbv}$ for $\mathrm{H}_{2} \mathrm{O}_{2}$ and $0.28 \pm 0.10 \mathrm{ppbv}$ for MHP. The mean values at night (20:00-02:00 LT) were 0.74 $\pm 0.62 \mathrm{ppbv}$ for $\mathrm{H}_{2} \mathrm{O}_{2}$ and $0.19 \pm 0.10 \mathrm{ppbv}$ for MHP. The mixing ratios of $\mathrm{H}_{2} \mathrm{O}_{2}$ and MHP are in agreement with those reported in the literature with $\mathrm{H}_{2} \mathrm{O}_{2}$ ranging between $0.5 \mathrm{ppbv}$ and $5 \mathrm{ppbv}$ and MHP ranging between several pptv and $2.7 \mathrm{ppbv}$ worldwide respectively (Hellpointner and Gäb, 1989; Hewitt and Kok, 1991; Das and Aneja, 1994; Watkins et al., 1995a, b; Jackson and Hewitt, 1996; Sauer et al., 1997, 2001; O'Sullivan et al. 1999; Morgan and Jackson, 2002; Moortgat et al., 2002; Grossmann et al., 2003; Lee et al., 1993, 1995, 1998, 2000, 2008; François et al., 2005; Xu and Chen, 2005; Walker et al., 2006; Kim et al., 2007).

Temporal profiles of the $\mathrm{H}_{2} \mathrm{O}_{2}$ and MHP mixing ratios for the time of the campaign are shown in Fig. 2. The maximum mixing ratio of $\mathrm{H}_{2} \mathrm{O}_{2}$ and MHP was found on $19 \mathrm{July}$, and this will be discussed in detail later. On sunny days with low levels of $\mathrm{NO}_{\mathrm{x}}$ and $\mathrm{SO}_{2}, \mathrm{H}_{2} \mathrm{O}_{2}$ showed pronounced diurnal variations, with peak mixing ratios in the afternoon (12:0018:00 LT) and low values at night and in the early morning. Sometimes, a second peak occurred in the evening between 20:00 and 02:00 LT. The diurnal variation of MHP is consistent with, but less pronounced than, that of $\mathrm{H}_{2} \mathrm{O}_{2}$. The general diurnal cycle of $\mathrm{H}_{2} \mathrm{O}_{2}$ observed at Backgarden was similar to that observed in earlier studies (Sauer et al., 2001; Grossmann et al., 2003). Over the 13 days of measurement, HMHP was detected in only a few samples; probably resulting from the heterogeneous decomposition of HMHP at glass surfaces during sampling (Neeb et al., 1997; Sauer et al. 2001). 


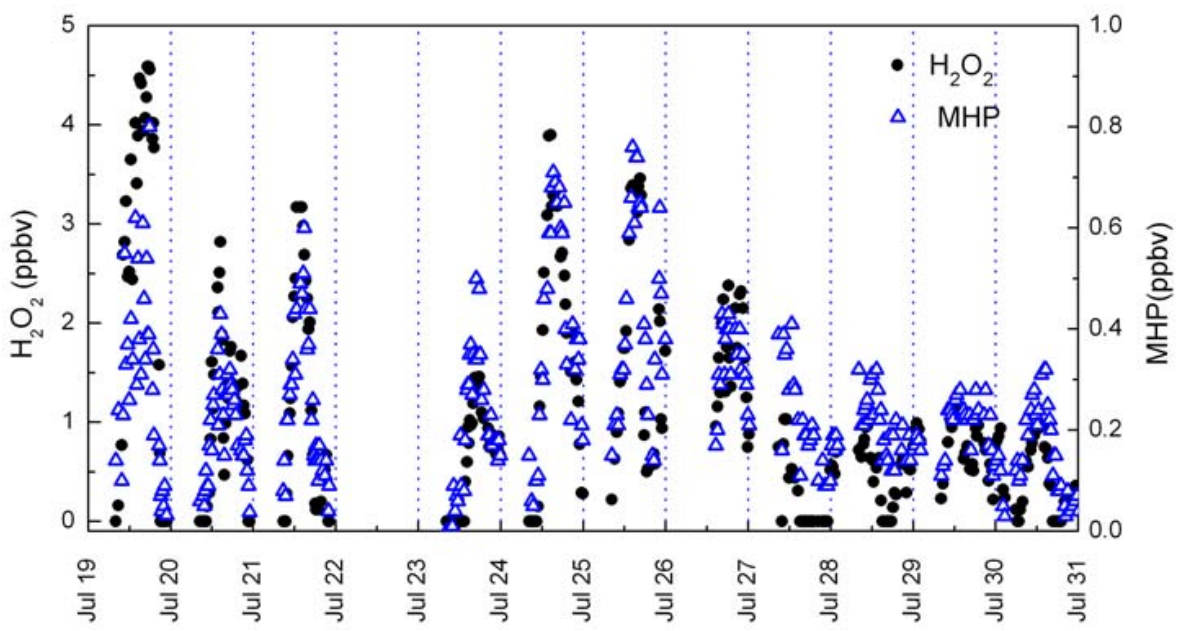

Fig. 2. Temporal profiles of atmospheric $\mathrm{H}_{2} \mathrm{O}_{2}$ and MHP mixing ratios from 19 to 30 July 2006 at Backgarden.

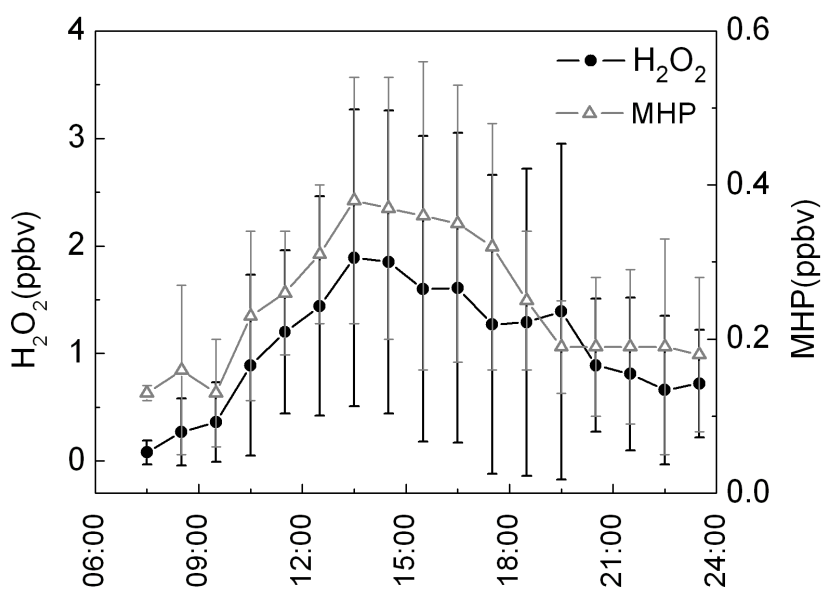

Fig. 3. Hourly averaged diurnal cycle for $\mathrm{H}_{2} \mathrm{O}_{2}$ (black circle) and MHP (gray triangle) at Backgarden from 19 to 30 July 2006 where vertical bars show the standard deviation.

Figure 3 depicts the hourly averaged mixing ratio profiles of $\mathrm{H}_{2} \mathrm{O}_{2}$ and MHP with the vertical bars showing the standard deviation of the measured values. A similar averaged diurnal profile for $\mathrm{H}_{2} \mathrm{O}_{2}$ has been reported (Das and Aneja, 1994; Sauer et al., 2001). The concentration of $\mathrm{H}_{2} \mathrm{O}_{2}$ began to rise in the morning $(\sim 10: 00 \mathrm{LT})$ and reached a maximum mixing ratio at 13:00 LT. The factors responsible for the $\mathrm{H}_{2} \mathrm{O}_{2}$ diurnal variation are discussed in detail in Sect. 3.2.2. The level of $\mathrm{H}_{2} \mathrm{O}_{2}$ remains relatively high in the afternoon and the mixing ratio decreased slowly from sunset to 24:00 LT. The diurnal profile of MHP is largely coincident with that of $\mathrm{H}_{2} \mathrm{O}_{2}$ in the daytime, but remained at an almost identical level after sunset. This slower loss of MHP at night can be explained by its lower level of solubility $\left(\mathrm{H}_{\mathrm{H}_{2} \mathrm{O}_{2}} / \mathrm{H}_{\mathrm{MHP}}=\sim 260\right.$, at $298 \mathrm{~K}$, Sander et al., 2003).
The diurnal profiles of the meteorological parameters and other trace gases measured at Backgarden from 19 to 30 July are shown in Fig. 4. As a compariosn, $\mathrm{H}_{2} \mathrm{O}_{2}$ and MHP are also shown in this figure. It is seen that when the $\mathrm{SO}_{2}$ level remained high, $>15 \mathrm{ppbv}$, in the morning or elevated during the day, $\mathrm{H}_{2} \mathrm{O}_{2}$ were detected in very low concentrations. These low concentrations resulted partly from the potentially significant interference of $\mathrm{SO}_{2}$ in the $\mathrm{H}_{2} \mathrm{O}_{2}$ measurement. Meanwhile, considering the fact that the loss of $\mathrm{H}_{2} \mathrm{O}_{2}$ due to $\mathrm{SO}_{2}$ reaction in the atmosphere would also be amplified by elevated $\mathrm{SO}_{2}$, we suggest that the diurnal cycle of $\mathrm{H}_{2} \mathrm{O}_{2}$ shown in Fig. 2 and Fig. 4 could reflect the variation trend of $\mathrm{H}_{2} \mathrm{O}_{2}$ in the atmosphere to some extent, although the uncertainty of $\mathrm{H}_{2} \mathrm{O}_{2}$ quantification occurs. However, it is noteworthy that at the $\mathrm{SO}_{2}$ level of $<10 \mathrm{ppbv}$, the condition for most of the daytime during the measurement period, the measurement of $\mathrm{H}_{2} \mathrm{O}_{2}$ were not significantly influenced, that is, most of our data were not significantly influenced by interference of $\mathrm{SO}_{2}$ and are reliable.

With regard to the meteorological conditions and levels of hydroperoxides, three distinct periods could be distinguished. (i) At the beginning of the measurement, 19-21 July, days were sunny with slight breeze, and hydroperoxides exhibited high mixing ratios during the day. (ii) The second period, 23-26 July, was influenced by typhoon Kaemi, which came across most of the PRD and resulted in heavily polluted conditions in the central and eastern PRD (Z. B. Yuan, 2007, personal communication). During this period, high levels of hydroperoxides were also observed at Backgarden on 24 and 25 July, two sunny days. (iii) During the last days of the campaign, 27-30 July, the local weather conditions were cloudy and rainy, and daytime values of hydroperoxides were low.

The low daytime average $\mathrm{H}_{2} \mathrm{O}_{2}$ values probably result from several factors, and the most important one is that the weak photochemical activity on cloudy days produces fewer 


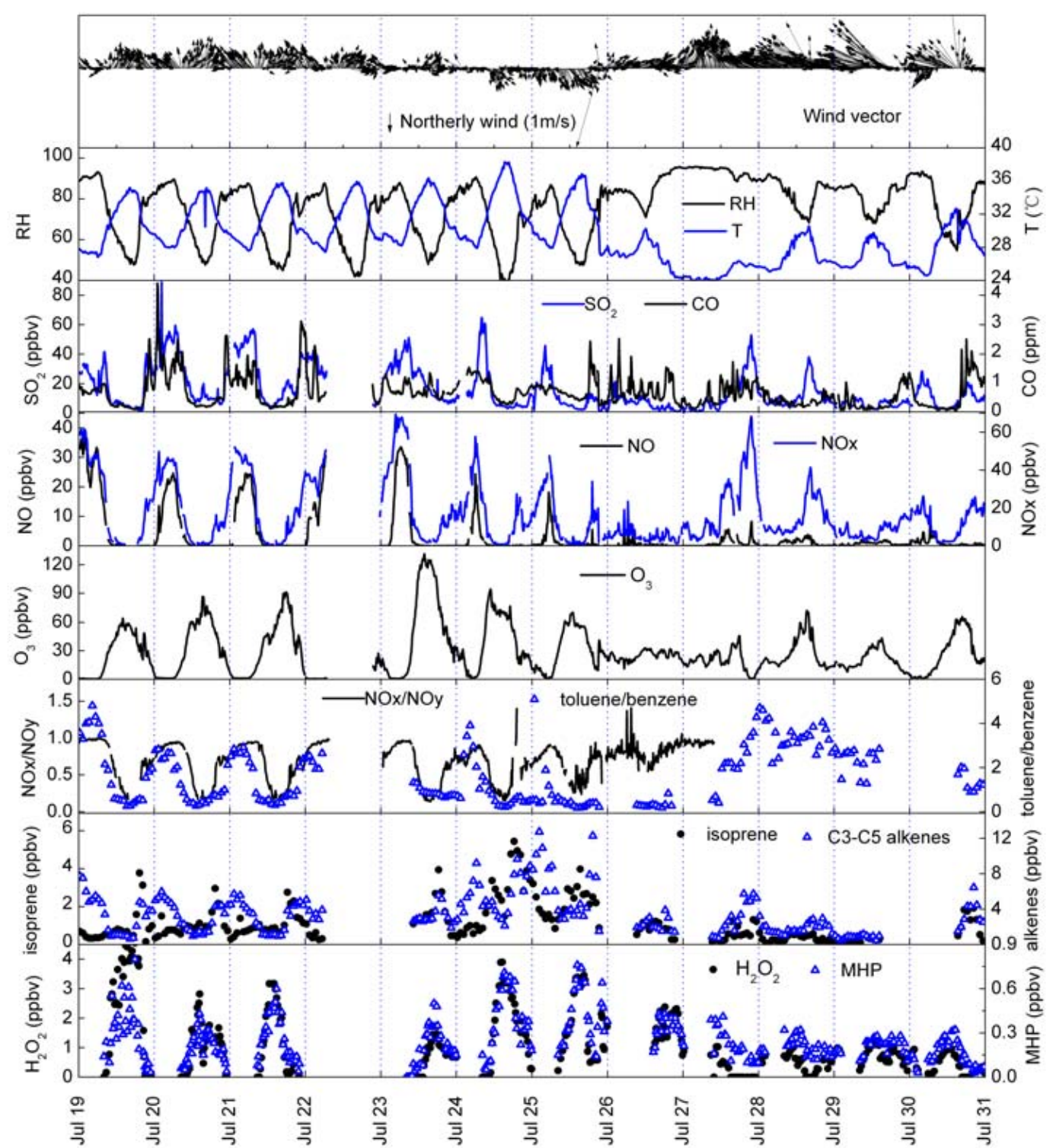

Fig. 4. Diurnal profile of wind speed, wind direction, temperature, relative humidity, $\mathrm{NO}, \mathrm{NO}_{\mathrm{x}}, \mathrm{SO}_{2}, \mathrm{CO}, \mathrm{O}_{3}, \mathrm{NO}_{\mathrm{x}} / \mathrm{NO}_{\mathrm{y}}$, toluene/benzene, isoprene, $\mathrm{C}_{3}-\mathrm{C}_{5}$ alkenes and $\mathrm{H}_{2} \mathrm{O}_{2}$ and MHP measured at Backgarden on 19-30 July 2006.

$\mathrm{HO}_{\mathrm{x}}$ radicals compared to sunny days, resulting in low-level production of hydroperoxides. Moreover, the high levels of $\mathrm{NO}_{\mathrm{x}}$ will significantly suppress the formation of hydroperoxides by consuming their precursors, peroxy radicals. Additionally, efficient scavenging of $\mathrm{H}_{2} \mathrm{O}_{2}$ on wet surfaces (leaves and fog droplets) and water-covered aerosols, in particular with a high level of $\mathrm{SO}_{2}$ and high relative humidity conditions, should partly account for the low levels of $\mathrm{H}_{2} \mathrm{O}_{2}$.

\subsection{Photochemistry on sunny days}

\subsubsection{Pattern of hydroperoxides and their precursors}

The meteorological conditions during 19-21 July at Backgarden can be treated as identical. On these three sunny days, the maximum temperature was $35^{\circ} \mathrm{C}$, and the relative humidity decreased from $\sim 90 \%$ in the early morning to $\sim 60 \%$ at noon. After reaching a minimum level of $\sim 45 \%$ in the afternoon, relative humidity increased gradually until the next morning. The wind speed was steady at around $0-3 \mathrm{~m} / \mathrm{s}$. The wind direction on 19 July turned clockwise via southeast in the morning to southwest at noon and back to southeast 
gradually in the late afternoon, and then remained southeast during the night. A similar pattern of wind direction was observed on the next two days.

The maximum mixing ratio of $\mathrm{H}_{2} \mathrm{O}_{2}$ and MHP was measured on 19 July, a sunny day with a slight breeze. As Fig. 4 shows, the concentration of $\mathrm{NO}_{\mathrm{x}}$ stayed very high from night to the early morning, with $32 \mathrm{ppbv}$ at 08:15 LT. The high $\mathrm{NO}_{\mathrm{x}}$ mixing ratio might have been caused by the accumulation of surface emission below the nocturnal inversion layer. After $08: 15 \mathrm{LT}$, the concentration of $\mathrm{NO}_{\mathrm{x}}$ decreased rapidly to $\sim 3 \mathrm{ppbv}$ at 10:30 LT, and remained at a relatively low level (1 $\sim 3$ ppbv) until sunset. The rapid drop of $\mathrm{NO}_{\mathrm{x}}$ probably resulted from the growing height of the mixing layer and changes in the wind direction. On the morning of 19 July, the wind direction turned clockwise via northeast (06:00 LT) to east (08:00 LT), and then to south (09:30 LT). Moreover, the chemistry conversion of $\mathrm{NO}_{\mathrm{x}}$ to $\mathrm{HNO}_{3}$ might also serve as an important sink for the $\mathrm{NO}_{\mathrm{x}}$. Since the concentrations of $\mathrm{HO}_{\mathrm{x}}$ radicals were high in the study region, $\mathrm{NO}$ could be fast converted to $\mathrm{NO}_{2}$ and then this $\mathrm{NO}_{2}$ reacted with $\mathrm{OH}$ radicals and formed $\mathrm{HNO}_{3}$, which would be in turn taken up in the aerosol. The increase of gas-phase $\mathrm{HNO}_{3}$ in the morning is consistent with the sudden drop of $\mathrm{NO}_{\mathrm{x}}(\mathrm{H} . \mathrm{Su}, 2008$, personal communication, Peking University), and this could be evidence of the chemistry conversion route. In addition to $\mathrm{NO}_{\mathrm{x}}$, the concentrations of $\mathrm{SO}_{2}$ and $\mathrm{CO}$ varied significantly in the morning. At 08:15LT, the concentrations of $\mathrm{SO}_{2}$ and $\mathrm{CO}$ were relatively high, with $41 \mathrm{ppbv}$ and 1 ppmv respectively; after this time, their concentrations decreased rapidly, e.g. $\sim 6 \mathrm{ppbv}$ and $\sim 0.3$ ppmv respectively at 10:30 LT, and remained at the relatively low levels until sunset. The mixing ratio of $\mathrm{H}_{2} \mathrm{O}_{2}$ began to increase markedly at $08: 45 \mathrm{LT}$ and reached $2.8 \mathrm{ppbv}$ at 10:30 LT, which is consistent with the sudden drop of $\mathrm{NO}_{\mathrm{x}}, \mathrm{SO}_{2}$ and $\mathrm{CO}$ detected, and the hydroperoxides showed a high level during the daytime. A similar diurnal trend for $\mathrm{NO}_{\mathrm{x}}, \mathrm{SO}_{2}$ and $\mathrm{CO}$ was observed during the daytime on 20-21 July. Chin et al. (1994) suggested that a $\mathrm{NO}_{\mathrm{x}} / \mathrm{NO}_{\mathrm{y}}$ ratio of $<0.3$ could be used to determine when an air-mass can be described as photochemically aged. The $\mathrm{NO}_{\mathrm{x}} / \mathrm{NO}_{\mathrm{y}}$ ratio was $<0.3$ between 12:00 and 17:00 LT during the three days, indicating that the air could be described as photochemically aged. This classification was supported also by the ratio of toluene/benzene almost lower than 0.5 . Li et al. (2005) suggested that a value of toluene/benzene below 0.5 is indicative of photochemically aged air due to the shorter atmospheric lifetime of toluene compared to benzene. Therefore, the high levels of hydroperoxides in this period were thought to be due to a combination of photochemically aged air with very high levels of $\mathrm{HO}_{\mathrm{x}}$, relatively low levels of $\mathrm{NO}_{\mathrm{x}}$ (compared to the other days during the observation at this site), and little surface deposition. This will be discussed in detail in Sect. 3.2.2.

As described previously, the formation of hydroperoxide can be represented by Reactions (R1) and (R2) ( $k_{1}$ is taken from Sander et al. (2003), at $298 \mathrm{~K})$ :

$\mathrm{HO}_{2}+\mathrm{HO}_{2} \stackrel{k_{1}}{\longrightarrow} \mathrm{H}_{2} \mathrm{O}_{2}+\mathrm{O}_{2}$

$k_{1}=1.5 \times 10^{-12} \mathrm{~cm}^{3}$ molecule ${ }^{-1} \mathrm{~s}^{-1}$

$\mathrm{HO}_{2}+\mathrm{HO}_{2}+(M) \stackrel{k}{\longrightarrow} \mathrm{H}_{2} \mathrm{O}_{2}+(M)$

( $M$ is air; the calculation of $k$ should take into account the pressure dependence and the temperature dependence and water vapor dependence.)

However, the NO reaction with peroxy radicals will compete with the formation of hydroperoxides, since the reactions of NO with peroxy radicals are faster than recombination reactions of peroxy radicals (Lee et al., 2000). At Backgarden, the average NO mixing ratio at 10:30-14:00 LT and 14:00-18:00 LT on 19-21 July were $\sim 280$ pptv and $\sim 80$ pptv respectively, and the mixing ratio of $\mathrm{HO}_{2}$ radicals was $\sim 2 \times 10^{9}$ molecule $/ \mathrm{cm}^{3}$ at noon. Using the $\mathrm{HO}_{2}$ average concentration, it can be obtained from a simple calculation that when the concentration of NO is $\sim 65 \mathrm{pptv}$, the reaction rates of $\mathrm{NO}-\mathrm{HO}_{2}$ and $\mathrm{HO}_{2}-\mathrm{HO}_{2}$ could be about equal. Hence, high levels of hydroperoxides detected in the daytime may be attributed to the moderate level of $\mathrm{NO}_{\mathrm{x}}$ and exceptionally high mixing ratio of $\mathrm{HO}_{2}$ radicals produced by oxidation of $\mathrm{VOC}$ and $\mathrm{CO}$ at Backgarden.

\subsubsection{Kinetics analysis}

In general, $j\left(\mathrm{NO}_{2}\right)$ can be used as an indicator for photochemically effective radiation. At Backgarden, $j\left(\mathrm{NO}_{2}\right)$ usually began to rise after 06:00(LT), reached maximum values of $\sim 8 \times 10^{-3} \mathrm{~s}^{-1}$ at noon and then returned to nearzero after 19:00 (LT) (personal communication by Bohn, B., Forschungszentrum Juelich). During 19-21 July, the maximum mixing ratios of $\mathrm{H}_{2} \mathrm{O}_{2}$ were observed during the daytime, and the diurnal variation of $\mathrm{H}_{2} \mathrm{O}_{2}$ was generally similar to that of $j\left(\mathrm{NO}_{2}\right)$, but the peak values were $2 \sim 3 \mathrm{~h}$ later. Generally, the photo-oxidant formation began about $3 \mathrm{~h}$ after the increase of radiation. The peak time of $\mathrm{H}_{2} \mathrm{O}_{2}$ approached that of $\mathrm{O}_{3}$ on 19 and 20 July, and the diurnal profiles of these two species were similar. Additionally, peroxy acetic acid (PAA), which is produced mainly by photo-oxidation of acetone and PAN, was often detected on 19-21 July. On the basis of this evidence, we can infer that $\mathrm{H}_{2} \mathrm{O}_{2}$ and MHP were produced, to a large extent, in the daytime by the local photochemical process during the three days.

Even more direct evidence of the photochemical formation of hydrogenperoxide can be obtained from the diurnal profiles of $\mathrm{HO}_{2}$, which were also measured at Backgarden. The $\mathrm{HO}_{2}$ concentration can be used to calculate the chemical production rate of $\mathrm{H}_{2} \mathrm{O}_{2}$. The mixing ratios of $\mathrm{HO}_{2}$ and $\mathrm{H}_{2} \mathrm{O}_{2}$ measured on 21 July are shown in Fig. 5. The mixing ratios of $\mathrm{H}_{2} \mathrm{O}_{2}$ and $\mathrm{HO}_{2}$ are almost zero at the high concentration of $\mathrm{NO}_{\mathrm{x}}$ before 09:30 (LT). The sharp increase of $\mathrm{H}_{2} \mathrm{O}_{2}$ at about 09:45 (LT) on 21 July coincides 


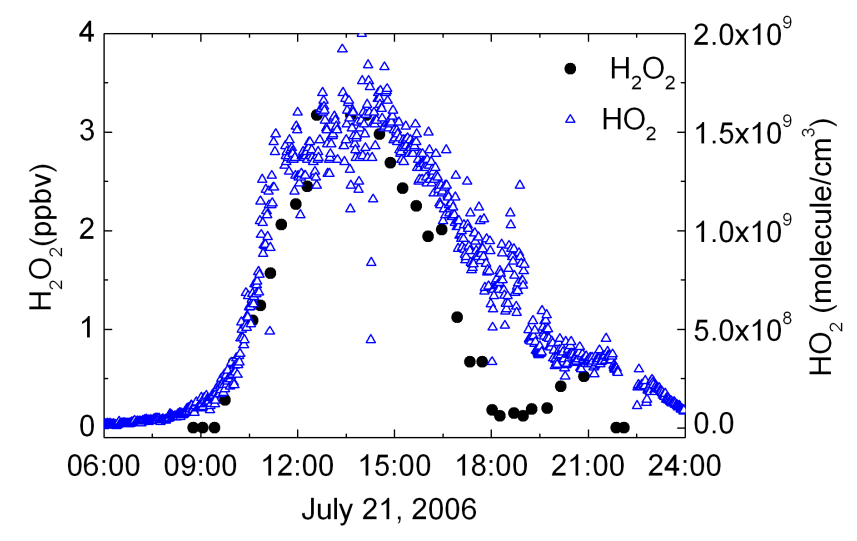

Fig. 5. Concentration profiles of $\mathrm{HO}_{2}$ and $\mathrm{H}_{2} \mathrm{O}_{2}$ measured at Backgarden on 21 July 2006.

with the decrease of the $\mathrm{NO}_{\mathrm{x}}, \mathrm{SO}_{2}$ and $\mathrm{CO}$ mixing ratios, which might be explained by vertical exchange and changes in the wind direction. In the morning, the wind direction turned clockwise via northeast $(07: 30 \mathrm{LT})$ to southeast (09:30 LT). During 10:00-12:00 LT, $\mathrm{H}_{2} \mathrm{O}_{2}$ continued to rise at a rate of $\sim 0.81 \mathrm{ppbv} \mathrm{h}^{-1}$, and the chemical production rate of $\mathrm{H}_{2} \mathrm{O}_{2}$ was $\sim 0.74 \mathrm{ppbv} \mathrm{h}^{-1}$, as determined from the $\mathrm{HO}_{2}$ concentration of $\sim 8.9 \times 10^{8}$ molecule $\mathrm{cm}^{-3}$. The calculation adopts the expressions recommended by Stockwell (1995), and the $\mathrm{HO}_{2}$ concentration and temperature uses the average value during the period, resulting in a rate coefficient of $6.5 \times 10^{-12} \mathrm{~cm}^{3}$ molecule ${ }^{-1} \mathrm{~s}^{-1}$ at $60 \%$ relative humidity. This indicates that most of the $\mathrm{H}_{2} \mathrm{O}_{2}$ increase was produced by in situ formation and the rest might be attributed to the net effect of vertical mixing. As shown in Fig. 5, the diurnal cycles of $\mathrm{HO}_{2}$ and $\mathrm{H}_{2} \mathrm{O}_{2}$ were, in general, consistent in the afternoon until 17:00 (LT); after that, the level of $\mathrm{H}_{2} \mathrm{O}_{2}$ had a weak correlation with that of $\mathrm{HO}_{2}$. It is worth noting that the relative humidity rose rapidly after 17:00 LT, while the concentration of NO remained low ( $\sim 30$ pptv) in the evening of 21 July.

The decrease of $\mathrm{H}_{2} \mathrm{O}_{2}$ during the late afternoon until the night may be attributed to the following reasons. First, considering the high solubility of $\mathrm{H}_{2} \mathrm{O}_{2}$ (Lind and Kok, 1994; O'Sullivan et al., 1996), the observed low levels can be explained by increased relative humidity $(\sim 80 \%$ at $21: 00 \mathrm{LT})$, which results in greater wet deposition of $\mathrm{H}_{2} \mathrm{O}_{2}$ at night than during the daytime. Secondly, the dry deposition of hydroperoxides on the Earth's surface will become very pronounced under a shallow inversion and at a low wind speed. The wind speed in the evening on 21 July was $\sim 1 \mathrm{~m} / \mathrm{s}$; therefore, dry deposition on the surface might have acted as an important sink for loss of $\mathrm{H}_{2} \mathrm{O}_{2}$. Moreover, Walcek (1987) and Wesley (1989) have found that the deposition rate of $\mathrm{H}_{2} \mathrm{O}_{2}$ over trees is much higher than in the free troposphere. Hence, the low mixing ratios of $\mathrm{H}_{2} \mathrm{O}_{2}$ might be due, in part, to the deposition on the leaves of the dense forests surround- ing the observation site. Furthermore, when the temperature decreased during the night, Henry's Law constant of $\mathrm{H}_{2} \mathrm{O}_{2}$ will increase, resulting in a removal of $\mathrm{H}_{2} \mathrm{O}_{2}$ from the gas phase into the liquid phase. As a result, the vast lake adjacent to the observation site might be substantially responsible for the decrease of $\mathrm{H}_{2} \mathrm{O}_{2}$. In addition, resulting from the limitation of the collection method, the loss of $\mathrm{H}_{2} \mathrm{O}_{2}$ by elevated $\mathrm{SO}_{2}$ during collection could also be an important reason for the decrease of gaseous $\mathrm{H}_{2} \mathrm{O}_{2}$ in the late afternoon.

\subsubsection{Impact of local meteorology on hydroperoxides}

The two sunny periods discussed here suggests that the hydroperoxide formation at Backgarden is, to a large extent, a local phenomenon. High levels of hydroperoxides were observed in the two sunny periods between 19-21 July and 24-25. The mixing ratios of hydroperoxides were similar in the two periods. Moreover, the diurnal variation of $\mathrm{H}_{2} \mathrm{O}_{2}$ showed a positive correlation with $\mathrm{O}_{3}$ on 24 July, as shown in Fig. 4, with the peak time of $\mathrm{H}_{2} \mathrm{O}_{2} 2-3 \mathrm{~h}$ later than that of $\mathrm{O}_{3}$. A ratio of toluene/benzene of $<0.5$ was observed between 12:00 LT on 24 July to 21:00 LT on 25 July, with a few exceptions in the early morning of 25 July. This indicates that during that time the air at Backgarden influenced by the typhoon front was photochemically aged. All the evidence indicates that local photochemical activity contributed substantially to the levels of hydroperoxides during 24 and 25 July.

It is worth noting that the dominant wind directions in the two sunny periods were opposite. As mentioned previously, southeasterly winds prevailed at the observation site during 19-21 July. On 24 and 25 July, the wind direction at Backgarden was northerly and veered to northwesterly in the afternoon, consistent with that of back trajectories obtained from NOAA (www.arl.noaa.gov). The wind speeds measured during the daytime of these two periods were similar, at $\sim 2 \mathrm{~m} / \mathrm{s}$, ensuring transport of air masses over distances $\sim 30 \mathrm{~km}$ between sunrise and the maximum observed photo-oxidant values. This suggests that the levels of hydroperoxides at Backgarden were not influenced by transport at low wind speed.

Thus, much of the variation of hydroperoxide mixing ratios observed at Backgarden on these sunny days can be attributed, to a large extent, to the local photochemical drive.

\subsection{Rain}

The heavy shower that started at 21:20 LT on 25 July and lasted for $40 \mathrm{~min}$ was brought by the typhoon Kaemi. At 17:00 LT, the wind direction turned from north to northwest, and the mixing ratios of $\mathrm{NO}_{\mathrm{x}}, \mathrm{SO}_{2}$ and $\mathrm{CO}$ began to rise, reaching $19 \mathrm{ppbv}, 9 \mathrm{ppbv}$ and $1.6 \mathrm{ppmv}$, respectively, at 21:00 LT, while $\mathrm{O}_{3}$ decreased from $54 \mathrm{ppbv}$ to $8 \mathrm{ppbv}$, as shown in Fig. 4. At the same time, the levels of hydroperoxides decreased rapidly, i.e. $\mathrm{H}_{2} \mathrm{O}_{2}$ went from $3.2 \mathrm{ppbv}$ to $0.9 \mathrm{ppbv}$ and MHP went from $0.6 \mathrm{ppbv}$ to $0.3 \mathrm{ppbv}$. These 
changes were interrupted at 21:20 LT when there was a heavy shower at Backgarden. When the rain began to fall, the temperature at ground level was $302 \mathrm{~K}$. The shower lasted for $\sim 40$ min with lightning activity. During the shower, three rainfall samples were collected and analyzed immediately. The maximum concentration of $\mathrm{H}_{2} \mathrm{O}_{2}$ in the rain samples, $21 \mu \mathrm{mol} / \mathrm{L}$, was detected at the beginning of the shower. This concentration is within the range from $0.1 \mu \mathrm{Mol} / \mathrm{L}$ to $300 \mu \mathrm{Mol} / \mathrm{L}$ reported by earlier studies (Hellpointner and Gäb, 1989; Jacob et al., 1990; Hewitt and Kok, 1991; Sauer et al., 1997; Morgan and Jackson, 2002). Moreover, MHP, which was seldom observed in rain samples (Hellpointner and Gäb, 1989; Pena et al., 2001; Reeves and Penkett, 2003), was detected in the rain samples at Backgarden at a concentration of $1.1 \mu \mathrm{mol} / \mathrm{L}$. This value may represent the concentration of MHP in cloud water. If we assume that the MHP value in the gas phase at the height of the cloud base was the same as that detected at ground level, $\sim 0.5 \mathrm{ppbv}$, the equilibrium concentration of MHP in cloud water is estimated to be $0.2 \mu \mathrm{M}$, on the basis of Henry's Law $\left(\mathrm{H}_{\mathrm{MHP}}=4.16 \times 10^{2} \mathrm{M} \mathrm{atm}^{-1}, 293 \mathrm{~K}\right.$, Sander et al., 2003). This estimated value is much smaller than the concentration of MHP detected in the rainwater, which implies a higher gas-phase level of MHP in the clouds compared to that at ground level. Similarly, this higher concentration above PBL (1 2 km) can be estimated by Henry's Law. The ambient temperature will decrease $6 \sim 7 \mathrm{~K}$ when the altitude increases by $1 \mathrm{~km}$; thus, the temperature at the height of the cloud base can be estimated to be $\sim 293 \mathrm{~K}$, while the temperature at ground level was $302 \mathrm{~K}$. According to the concentration of MHP detected in the rain $(1.1 \mu \mathrm{Mol} / \mathrm{L})$, the gas-phase MHP mixing ratio above $\mathrm{PBL}$ was $\sim 2.6 \mathrm{ppbv}$. This estimated value is slightly higher than those reported for earlier field studies in which MHP was detected directly by aircraft (O'Sullivan et al., 1999; Lee et al., 2000). MHP may be of great importance in the redistribution of $\mathrm{OH}$ radicals along with the driving force of atmospheric chemistry (Wennberg et al., 1998; Cohan et al., 1999; Ravetta et al., 2001; Mari et al., 2000). Our measurement may be new evidence for the existence of high mixing ratios of MHP above the PBL.

The levels of hydroperoxides after the shower lend support to the deduction that high mixing ratios of hydroperoxides occur in the PBL. $\mathrm{H}_{2} \mathrm{O}_{2}$ and MHP exhibited relatively high mixing ratios of $2.1 \mathrm{ppbv}$ and $0.64 \mathrm{ppbv}$, respectively, immediately after the shower; meanwhile, the mixing ratios of $\mathrm{NO}_{\mathrm{x}}, \mathrm{SO}_{2}$ and $\mathrm{CO}$ decreased to relatively low values due to the dilution and scavenging effects, as shown in Fig. 4. The mixing ratios of hydroperoxides after the shower were even higher than they were before the shower. Considering the much higher solubility of $\mathrm{H}_{2} \mathrm{O}_{2}$ than that of $\mathrm{NO}_{\mathrm{x}}, \mathrm{SO}_{2}$ and $\mathrm{CO}$, we suggest that vertical convection might contribute significantly to the increased $\mathrm{H}_{2} \mathrm{O}_{2}$ and MHP mixing ratios, for the following two reasons. First, the air mass above and in the boundary layer may be carried down to the land surface when rain falls. As a result, the gas-phase $\mathrm{H}_{2} \mathrm{O}_{2}$ above the PBL that was not washed out by the shower might affect the mixing ratio at low altitudes. Second, the falling rain and rainwater on the ground (e.g. on the leaves of plants) might release $\mathrm{H}_{2} \mathrm{O}_{2}$ and MHP into the gas phase during and after the shower, because of the decrease of Henry's Law constants due to the increase of temperature with descending altitude. In addition, owing to the low level of solubility and its estimated 2-3 days atmospheric lifetime (Cohan et al., 1999; Wang and Chen, 2006), a fraction of the increased MHP might be introduced partly by the advection of typhoon from other regions. Moreover, although the measurement of VOC was interrupted in the hours following the shower, the low mixing ratio of alkenes ( $\sim 2 \mathrm{ppbv})$ at around 21:20 LT indicated that the ozonolysis of alkenes might have a minor impact on the level of hydroperoxides during the shower.

Overall, this measurement of hydroperoxides during the shower may provide evidence for the high mixing ratio of hydroperoxides, particularly MHP, above the boundary layer. This mixing ratio of MHP might potentially influence the redistribution of $\mathrm{HO}_{\mathrm{x}}$ and $\mathrm{RO}_{\mathrm{x}}$ radical in the PRD on a regional scale.

\subsection{Formation of hydroperoxides by ozonolysis}

The ozonolysis of alkenes (e.g. isoprene, terpenes, ethene, propene and isobutene) can produce a variety of peroxides (Gäb et al., 1985, 1995; Becker et al., 1990, 1993).

It is proposed that ozonolysis proceeds by the initial insertion of the ozone into the double bond forming a primary ozonide, and decomposes to form excited Criegee intermediates (ECI) $\left[\mathrm{R}_{1} \mathrm{R}_{2} \mathrm{COO}\right]^{*}$ and a carbonyl compound (Gäb et al., 1985). ECI are biradicals with excess energy, and some of them will become stabilized Criegee intermediates (SCI) $\mathrm{R}_{1} \mathrm{R}_{2} \mathrm{COO}$ by interaction with the medium, and the SCI can react further to produce hydroperoxides. Recent laboratory studies have revealed that $\mathrm{R}_{1} \mathrm{R}_{2} \mathrm{C}(\mathrm{OH}) \mathrm{OOH}$ can be formed by the reaction of SCI with water vapor (Horie et al., 1994; Neeb et al., 1997; Sauer et al., 1999; Valverde-Canossa et al., 2001). This $\mathrm{R}_{1} \mathrm{R}_{2} \mathrm{C}(\mathrm{OH}) \mathrm{OOH}$ decomposes primarily to $\mathrm{H}_{2} \mathrm{O}_{2}$ and a carbonyl compound $\mathrm{R}_{1} \mathrm{COR}_{2}$, as shown in the following reactions ( $\mathrm{R}_{1}$ and $\mathrm{R}_{2}$ are alkyl groups):

$$
\begin{aligned}
& \mathrm{R}_{1} \mathrm{R}_{2} \mathrm{COO}+\mathrm{H}_{2} \mathrm{O} \rightarrow \mathrm{R}_{1} \mathrm{R}_{2} \mathrm{C}(\mathrm{OH}) \mathrm{OOH} \\
& \mathrm{H}_{2} \mathrm{COO}+\mathrm{H}_{2} \mathrm{O} \rightarrow \mathrm{HOCH}_{2} \mathrm{OOH}\left(\mathrm{R}_{1}=\mathrm{H}, \mathrm{R}_{2}=\mathrm{H}\right) \\
& \mathrm{R}_{1} \mathrm{R}_{2} \mathrm{C}(\mathrm{OH}) \mathrm{OOH} \rightarrow \mathrm{R}_{1} \mathrm{COR}_{2}+\mathrm{H}_{2} \mathrm{O}_{2}
\end{aligned}
$$

There is some evidence that $\mathrm{H}_{2} \mathrm{O}_{2}$ and MHP were formed in the evening. As shown in Fig. 6, a high $\mathrm{H}_{2} \mathrm{O}_{2}$ mixing ratio was detected after sunset (19:20 LT) on 24 July; in particular, a second peak ( $\sim 1.9 \mathrm{ppbv})$ was observed during the evening. Relatively high mixing ratios of alkenes $(\sim 8 \mathrm{ppbv})$, particularly isoprene $(\sim 5 \mathrm{ppbv})$, were detected during the evening on 24 July, compared to the other nights. The mixing ratio of 


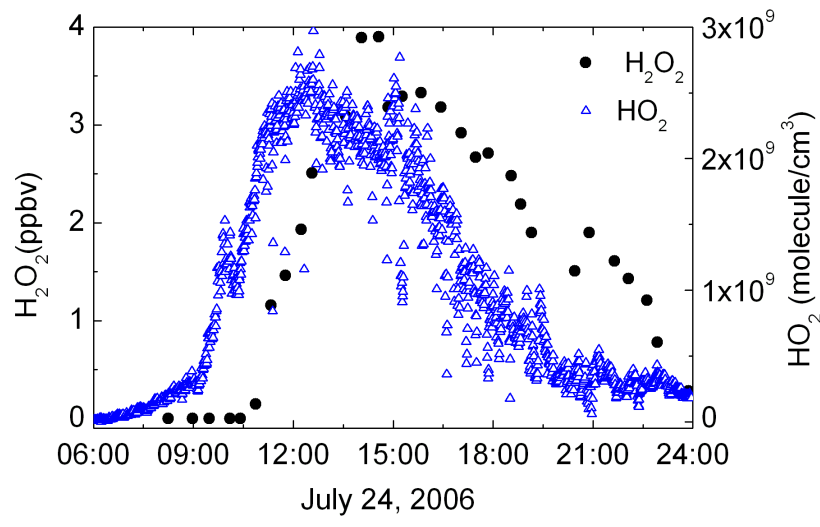

Fig. 6. Diurnal profiles of $\mathrm{HO}_{2}$ and $\mathrm{H}_{2} \mathrm{O}_{2}$ measured at Backgarden on 24 July 2006, showing a high level of $\mathrm{H}_{2} \mathrm{O}_{2}$ at night.

$\mathrm{H}_{2} \mathrm{O}_{2}$ at 21:00 LT was about half of the maximum value observed during the daytime. However, the level of $\mathrm{HO}_{2}$ at this time was $\sim 3 \times 10^{8}$ molecules $\mathrm{cm}^{-3}$, only $\sim 13 \%$ of the maximum value observed at midday, as shown in Fig. 6 . This high level of $\mathrm{H}_{2} \mathrm{O}_{2}$ production cannot be attributed to only the recombination of $\mathrm{HO}_{2}$ radicals, suggesting that the formation via the ozonolysis of alkenes under moist atmospheric conditions (70\% relative humidity) contributes substantially to the production $\mathrm{H}_{2} \mathrm{O}_{2}$ during the evening. Further evidence for this pathway comes from the fact that $\mathrm{HOCH}_{2} \mathrm{OOCH}_{2} \mathrm{OH}$ (BHMP) was observed for a considerable length of time only during the night of 24 July. The apparent precursor of BHMP is HMHP (Gäb et al., 1985), which is a unique product of the ozonolysis of exocyclic biogenic alkenes (Valverde-Canossa et al., 2001). HMHP is formed by $\mathrm{CH}_{2} \mathrm{OO}$ biradicals, which are produced in the ozonolysis of terminal alkenes, as shown in Reaction (R4), while the formation of BHMP can be expressed by Reaction (R6):

$\mathrm{HOCH}_{2} \mathrm{OOH}+\mathrm{HOCH}_{2} \mathrm{OOH} \rightarrow \mathrm{HOCH}_{2} \mathrm{OOCH}_{2} \mathrm{OH}+\mathrm{H}_{2} \mathrm{O}$

Therefore, the reaction of alkenes with $\mathrm{O}_{3}$ can be suggested as a source of hydroperoxides at night at the Backgarden site. Grossmann et al. (2003) proposed that the ozonolysis of alkenes was a source of $\mathrm{H}_{2} \mathrm{O}_{2}$ at night at Pabstthum, Germany.

It is worth noting that MHP had a diurnal profile similar to that of $\mathrm{H}_{2} \mathrm{O}_{2}$ in the evening at Backgarden, and MHP also exhibited a second peak $0.4 \mathrm{ppbv}$ at night on 24 July. This level of MHP at night was much higher than those reported for other continents (Hellpointner and Gäb, 1989; Jackson and Hewitt, 1996; Sauer et al., 2001; Grossmann et al., 2003; Walker et al., 2006).

From Fig. 4, it can be seen that relatively high levels of hydroperoxides were detected in the evening of 20 and 21 July, which coincided with the increase of $\mathrm{C}_{3}-\mathrm{C}_{5}$ alkenes, especially isoprene, measured in the same time periods. Moreover, BHMP was also observed in the morning and the afternoon of 25 July in addition to the afternoon and night of 24 July. Noticeably, when BHMP was detected, the mixing ratios of $\mathrm{C}_{3}-\mathrm{C}_{5}$ alkenes, particularly isoprene, propylene, 1butene and 1-pentene were high, as shown in Fig. 4. Thus, we suggest that high levels of alkenes, especially isoprene, are favorable for the formation organic hydroperoxides. Besides BHMP, the relatively high level of PAA was often detected on 23-25 July in addition to 19-21 July mentioned in Sect. 3.2.2. The maximum mixing ratio of PAA during the observation was observed in the afternoon on 24 July, on which PAN also exhibited a high level of $\sim 3 \mathrm{ppbv}$ (B. Wang, 2008, personal communication, Peking University). Hence, we suggest that the high levels of PAN and strong solar radiation in the daytime could favor the formation of PAA. It is noteworthy that PAA was often detected after sunset on 20-21 and 23-25 July, implying that PAA might also be formed in the absence of photo-oxidation. However, to our best knowledge, PAA has not been reported as a product of the ozonolysis of alkenes, and the relevant mechanism is unclear and need further investigation. The solubility of BHMP is higher than $\mathrm{H}_{2} \mathrm{O}_{2}\left(\mathrm{H}_{\mathrm{BHMP}}=6.0 \times 10^{5} \mathrm{M} \mathrm{atm}^{-1}\right.$, $293 \mathrm{~K}$ ), thus, it could enter into the aqueous phase easily. BHMP could easily decompose and convert to $\mathrm{H}_{2} \mathrm{O}_{2}$, thus it might take part in the formation of sulfate and SOA in the form of $\mathrm{H}_{2} \mathrm{O}_{2}$. PAA is an important acid in its own right and could decompose easily into acetic acid and $\mathrm{H}_{2} \mathrm{O}_{2}$ under typical tropospheric conditions. As a result, PAA could play a role in acid deposition both as an oxidant and an acid.

\subsection{Hydroperoxide contribution to aerosols}

\subsubsection{Role of hydroperoxides in the formation of secondary sulfate}

Atmospheric aerosols are responsible for the deterioration of air quality in industrialized areas and adversely affect human health and welfare. A major component of aerosols in North America, Europe, and Asia is secondary sulfate resulting from the atmospheric oxidation of anthropogenically emitted sulfur dioxide $\left(\mathrm{SO}_{2}\right)$ (US Environmental Protection Agency, 2001). Therefore, the oxidants and oxidation processes involved in the formation and growth of secondary sulfate are important subject in need of further study, especially when taking into account the long-range transport of anthropogenic sulfate aerosols (Perry et al., 1999). During the PRIDE-PRD'06 campaign, sulfate present in the aerosol phase was determined to be a major component, $10 \sim 60 \%$, of $\mathrm{PM}_{2.5}$ mass (S. Guo, 2008, personal communication, Peking University). The main oxidation process for $\mathrm{SO}_{2}$ in the atmospheric gas phase is its reaction with $\mathrm{OH}$ radicals.

However, it is suggested that the aqueous phase reaction with $\mathrm{H}_{2} \mathrm{O}_{2}$ and $\mathrm{O}_{3}$ is the main route for $\mathrm{SO}_{2}$ oxidation. The aqueous-phase oxidation with $\mathrm{H}_{2} \mathrm{O}_{2}$ accounts for $60 \sim 80 \%$ of the total oxidation of $\mathrm{SO}_{2}$ in the atmosphere, especially when the $\mathrm{pH}$ is $<4.5$ (Penkett et al., 1979; Calvert et al., 
1985). Organic hydroperoxides such as MHP, HMHP and PAA are also able to oxidize $\mathrm{SO}_{2}$ (Lind et al., 1987; Zhou and Lee, 1992). At the $\mathrm{pH}$ range of atmospheric interest $(\mathrm{pH}=2-7)$ most of the $\mathrm{S}(\mathrm{IV})$ species is in the form of the bisulfite ion $\left(\mathrm{HSO}_{3}^{-}\right)$. Reactions leading to the formation of sulfuric acid by hydroperoxides in the aqueous phase are as follows (Hoffmann and Edwards, 1975):

$\mathrm{SO}_{2}+\mathrm{H}_{2} \mathrm{O} \leftrightarrow \mathrm{HSO}_{3}^{-}+\mathrm{H}^{+}$

$\mathrm{HSO}_{3}^{-}+\mathrm{H}_{2} \mathrm{O}_{2} \rightarrow \mathrm{HSO}_{4}^{-}+\mathrm{H}_{2} \mathrm{O}$

$R_{a}=-d[S(I V)] / d t=k_{8}\left[\mathrm{H}^{+}\right]\left[\mathrm{H}_{2} \mathrm{O}_{2}\right][\mathrm{S}(\mathrm{IV})]\left(\mathrm{M} \mathrm{s}^{-1}\right)$

$R_{a}^{\prime}=10^{-6} L R_{a} \quad\left(\mathrm{~mol}(\mathrm{~L} \text { of air })^{-1} \mathrm{~s}^{-1}\right)$

$k_{8}=7.5 \pm 1.6 \times 10^{7} \mathrm{M}^{-1} \mathrm{~s}^{-1}$ at $298 \mathrm{~K}$, (Seinfeld and Pandis, $1998), L$ is the liquid water content $\left(\mathrm{g} \mathrm{H}_{2} \mathrm{O} / \mathrm{m}^{3}\right.$ air).

While the total amount of dissolved $\mathrm{S}(\mathrm{IV})$ always exceeds that predicted by Henry's Law for $\mathrm{SO}_{2}$ alone, and is enhanced at high $\mathrm{pH}$ values, the reaction of $\mathrm{H}_{2} \mathrm{O}_{2}$ with $\mathrm{S}(\mathrm{IV})$ is catalyzed by $\mathrm{H}^{+}$ions and is faster at low $\mathrm{pH}$. Therefore, the rate of $\mathrm{S}(\mathrm{IV})$ reaction with $\mathrm{H}_{2} \mathrm{O}_{2}$ is practically independent of $\mathrm{pH}$ over the $\mathrm{pH}$ range of atmospheric interest (Schwartz et al., 1984). Similarly, the reaction of $\mathrm{HSO}_{3}^{-}$with MHP is independent of $\mathrm{pH}$. The oxidation of $\mathrm{S}(\mathrm{IV})$ to $\mathrm{S}(\mathrm{VI})$ by $\mathrm{H}_{2} \mathrm{O}_{2}$ in the aqueous phase is so fast that it can deplete the limiting compound within $1 \mathrm{~h}$ at $\mathrm{pH}<4.5$ (Kelly et al., 1985). Considering the rapid loss of $\mathrm{H}_{2} \mathrm{O}_{2}$ into the aqueous phase due to its high Henry's Law coefficient, we propose that $\mathrm{H}_{2} \mathrm{O}_{2}$ may contribute significantly to the formation of sulfate $\left(\mathrm{SO}_{4}^{2-}\right)$ on droplets and aerosols covered by a water-soluble layer.

Evidence of $\mathrm{SO}_{4}^{2-}$ formation by $\mathrm{H}_{2} \mathrm{O}_{2}$ oxidation was seen on 21 July, as shown in Fig. 7. Between 13:30 and 15:30 LT, the mixing ratio of $\mathrm{NO}_{\mathrm{x}}, \mathrm{SO}_{2}$ and especially $\mathrm{CO}$ varied slightly, the wind speed remained constant at $\sim 2 \mathrm{~m} \mathrm{~s}^{-1}$ and the wind direction was southwesterly. Therefore, although it is well recognized that the sulfate can be transported to long distance (Perry et al., 1999), the transport might have a minor effect on the concentration of sulfate at the observation site during the above two-hour period. The high mixing ratio of $\mathrm{H}_{2} \mathrm{O}_{2}$ lasted from midday to the afternoon, while $\mathrm{SO}_{2}$ displayed relatively low mixing ratios but increased slightly after midday. During the time period of 13:30-15:30 LT, the averaged and the maximum mixing ratios of $\mathrm{SO}_{2}$ are $6.5 \mathrm{ppbv}$ and 9.9 ppbv respectively, and these $\mathrm{SO}_{2}$ levels could only result in 10 20\% loss of $\mathrm{H}_{2} \mathrm{O}_{2}$ during collection; thus, it is reasonable to think that the $\mathrm{SO}_{2}$ interference on measurement of $\mathrm{H}_{2} \mathrm{O}_{2}$ was minor and the mixing ratios of $\mathrm{H}_{2} \mathrm{O}_{2}$ detected could reflect the situation of the real atmosphere. Meanwhile, the concentration of sulfate in the aerosol phase increased at a rate of $\sim 1.7 \times 10^{-11} \mathrm{~mol} \mathrm{~m}^{-3} \mathrm{~s}^{-1}$ between 13:30 and 15:30LT. During this time, the relative humidity was $\sim 50 \%$, and we used $8.0 \times 10^{-4} \mathrm{~g} \mathrm{H}_{2} \mathrm{O} / \mathrm{m}^{3}$ air as a general estimate of liquid water content in the ground-level

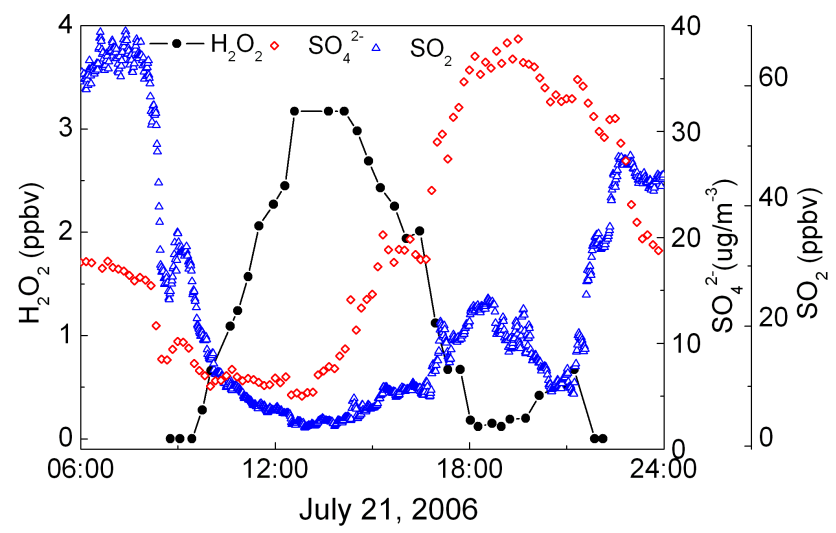

Fig. 7. Diurnal profiles of $\mathrm{H}_{2} \mathrm{O}_{2}$, sulfate and $\mathrm{SO}_{2}$ on 21 July.

air mass. Considering the aerosols in PRD region was generally acidic (M.-Q. Huo, 2008, personal communication, Peking University), we estimate the $\mathrm{pH}$ of the aerosols to be $4 \sim 5$. On the basis of the average measured concentrations, with $1.0 \times 10^{7}$ molecule $\mathrm{cm}^{-3}$ for $\mathrm{OH}, 6.5 \mathrm{ppbv}$ for $\mathrm{SO}_{2}, 2.8 \mathrm{ppbv}$ for $\mathrm{H}_{2} \mathrm{O}_{2}$ and $50 \mathrm{ppbv}$ for $\mathrm{O}_{3}$, the sulfate production rate is $1.4 \times 10^{-12} \mathrm{~mol} \mathrm{~m}^{-3} \mathrm{~s}^{-1}$ in the aqueous phase (using Eq. (1) and (2)) and $3.5 \times 10^{-12} \mathrm{~mol} \mathrm{~m}^{-3} \mathrm{~s}^{-1}$ in the gas phase, resulting in a combined sulfate production in both phases of $\sim 4.9 \times 10^{-12} \mathrm{~mol} \mathrm{~m}^{-3} \mathrm{~s}^{-1}$. This estimated sulfate production is much smaller than the measured value of $1.7 \times 10^{-11} \mathrm{~mol} \mathrm{~m}^{-3} \mathrm{~s}^{-1}$, which indicates that other processes are responsible for the missed source of sulfate. It is worth noting that the calculated production of sulfate mentioned above includes only the production in the gas phase and in the aqueous bulk of droplets. The heterogeneous chemistry on the surface of droplets and aerosols is potentially important (Li et al., 2006, 2007; Ammann and Pöschl, 2007; Pöschl et al., 2007; Chen et al., 2008), but it is not taken into account in the above estimation. Jayne et al. (1990) observed that the uptake of $\mathrm{SO}_{2}$ into water droplets was faster than predicted on the basis of the known kinetics in bulk solution, and they suggested that a surface complex was formed between $\mathrm{SO}_{2}$ and $\mathrm{H}_{2} \mathrm{O}$ at the interface. Vácha et al. (2004) suggested that the concentration of $\mathrm{H}_{2} \mathrm{O}_{2}$ is increased in the interfacial region by $\sim 50 \%$ compared to the bulk. Chung et al. (2005) pointed out that salts containing ammonium ions were found to increase the solubility of $\mathrm{H}_{2} \mathrm{O}_{2}$ by up to a factor of two compared to pure water. Hasson and Paulson (2003) found that the concentration of $\mathrm{H}_{2} \mathrm{O}_{2}$ within aerosols was of the order of $10^{-3} \mathrm{M}$, which is one order of magnitude higher than the expected concentration based on the solubility of $\mathrm{H}_{2} \mathrm{O}_{2}$ in liquid water $\left(\sim 1 \times 10^{-4} \mathrm{M}\right)$. Moreover, Chen et al. (2008) recommended that the interfacial reaction should be taken into account in the generalized aqueous phase especially for a rapid reaction. Combining all these intriguing hints with our estimation, we suggest that the surface heterogeneous phase reaction, here, 


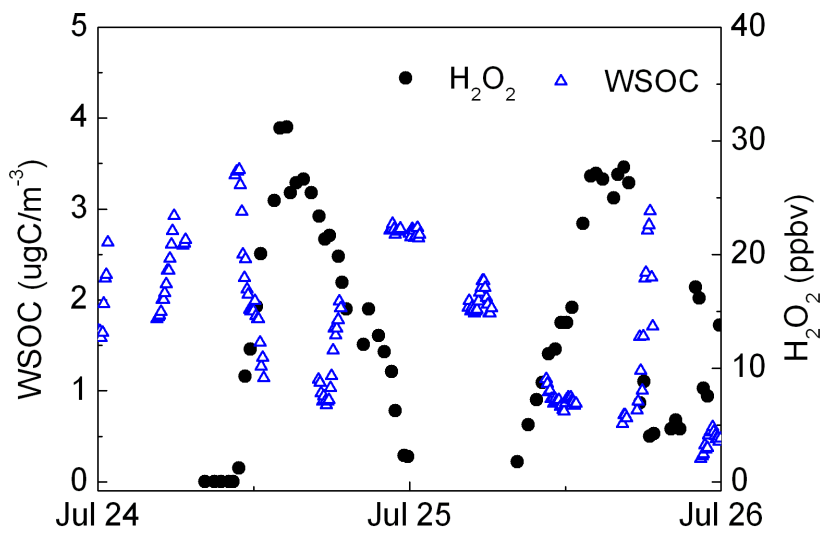

Fig. 8. Diurnal profiles of $\mathrm{H}_{2} \mathrm{O}_{2}$ and WSOC measured on 24 and 25 July.

the heterogeneous reaction of $\mathrm{SO}_{2}$ with $\mathrm{H}_{2} \mathrm{O}_{2}$ might make a substantial contribution to sulfate production. Clearly, the mechanism, kinetics parameters and yield of sulfate formation regarding the heterogeneous reactions need further investigation.

Recent studies have revealed that the enhanced acidity of the aerosol can catalyze particle-phase heterogeneous reactions of atmospheric organic carbonyl species (Jang et al., 2002, 2003; Iinuma et al., 2004). The reactions of $\mathrm{SO}_{2}$ with hydroperoxides produce sulfate, and provide hydrogen ions continuously for heterogeneous reaction systems.

3.5.2 Contribution to the formation of secondary organic aerosol (SOA) in aerosols

SOA formed through oxidation of atmospheric VOC contributes to the global aerosol burden through both biogenic and anthropogenic precursors. The biogenic fraction of SOA contributes the most, with estimates varying between $8 \mathrm{Tg} \mathrm{yr}^{-1}$ and $40 \mathrm{Tg} \mathrm{yr}^{-1}$ (Penner et al., 2001). Recent laboratory studies have revealed that acid-catalyzed heterogeneous reaction of isoprene and its gas-phase oxidation product with hydrogen peroxide lead to the formation of SOA (Claeys et al., 2004b; Böge et al., 2006; Kroll et al., 2006). This new route may explain the formation of water-soluble organic compounds (WSOC), which include hydroxyl and/or carboxyl functional groups and represent a considerable fraction of the SOA (Saxena and Hildemann, 1996).

Some evidence from the PRIDE-PRD'06 study implies that a negative correlation might exist between the observed hydroperoxides and the concentration of WSOC. Fig. 8 shows the measured concentrations of $\mathrm{H}_{2} \mathrm{O}_{2}$ and WSOC, and it can be seen that the diurnal variations of the two kinds of species are generally opposite.

It is generally accepted that the formation of SOA from biogenic hydrocarbons emitted by terrestrial vegetation is via gas-phase photochemical reactions followed by gas- to-particle partitioning (Seinfeld and Pandis, 1998). In the atmosphere, hydroperoxides and WSOC are competitive in their formation reactions, involving the intermediates $\mathrm{R}_{1} \mathrm{R}_{2} \mathrm{COO}$ and $\mathrm{HO}_{2}$ radicals. Additionally, WSOC may be produced by acid-catalyzed heterogeneous oxidation with hydrogen peroxide as reported (Claeys et al., 2004b; Böge et al., 2006; Kroll et al., 2006), resulting in the consumption of hydrogen peroxide. Thus, a negative correlation of atmospheric hydrogen peroxide with aerosol-phase WSOC could be expected to some extent. Recently, the laboratory study revealed that the aqueous-phase ozonolysis of isoprene and its gas-phase oxidation product may serve as a potentially important route for the formation of oxidants, including $\mathrm{H}_{2} \mathrm{O}_{2}$ (Chen et al., 2008). The field evidence indicated that the sampled particles are capable of generating $\mathrm{H}_{2} \mathrm{O}_{2}$ in aqueous solution (Arellanes et al., 2006). Although it is difficult to distinguish quantitatively the contribution of gas-phase $\mathrm{H}_{2} \mathrm{O}_{2}$ and $\mathrm{H}_{2} \mathrm{O}_{2}$ generated in aqueous phase, our observations might provide some evidence that atmospheric $\mathrm{H}_{2} \mathrm{O}_{2}$ potentially contributes to the formation of WSOC and a negative correlation might exist between the two kinds of species, as shown in Fig. 8. Combining this $\mathrm{H}_{2} \mathrm{O}_{2}$-WSOC negative correlation and the $\mathrm{H}_{2} \mathrm{O}_{2}$-sulfate negative correlation as shown in Fig. 7, the results of our field observations seem to imply that hydrogen peroxide and sulfuric acid potentially play a potential important role in the formation of WSOC through acid-catalyzed heterogeneous oxidation with hydrogen peroxide. In this study, we attempt to give a field evidence for the $\mathrm{H}_{2} \mathrm{O}_{2}$-WSOC relationship for the first time. Actually, our given evidence is still weak, and more field evidences should be provided in the future.

In addition to $\mathrm{H}_{2} \mathrm{O}_{2}$, organic hydroperoxides, especially HMHP and MHP, potentially play a role in the formation of WSOC. As mentioned above, HMHP can decompose to $\mathrm{H}_{2} \mathrm{O}_{2}$ and formaldehyde in the aqueous phase (O'Sullivan et al., 1996; Chen et al., 2008), which can subsequently participate in the formation of WSOC in the form of $\mathrm{H}_{2} \mathrm{O}_{2}$. It has been shown that the concentrations of $\mathrm{H}_{2} \mathrm{O}_{2}$ and MHP are similar in many parts of the atmosphere (Reeves and Penkett, 2003). Although the Henry's Law constant of MHP in pure water is much lower than that of $\mathrm{H}_{2} \mathrm{O}_{2}$, the role of MHP in the atmospheric aqueous phase may be much more important than that estimated by its Henry's Law constant in pure water. It is worth noting that formaldehyde was found in the aerosol at concentrations 1000-fold higher than the equilibrium concentration calculated only from its gasphase formaldehyde and aqueous aerosol (Klippel and Warneck, 1978). This unexpected partitioning may be because formaldehyde in the aqueous aerosol is complexed with some soluble species (Facchini et al., 1992). The Henry's Law constant of formaldehyde obtained in this case is usually called its effective Henry's Law constant. However, to our knowledge, a similar study for enhanced solubility of MHP in the aqueous phase has not been reported. Considering the potential importance of MHP in the aqueous-phase reaction, its 
effective Henry's Law constant in solutions regarding real atmospheric conditions needs further study.

In summary, hydroperoxides play an important role substantially in the formation of secondary sulfate and potentially in the formation of organic aerosols. First, hydroperoxides oxidize $\mathrm{SO}_{2}$ into sulfate aerosols and simultaneously produce hydrogen ions. Second, with the increase of hydrogen ions derived from the above reaction, hydroperoxides will effectively oxidize organic compounds into WSOC by acid-catalyzed heterogeneous reactions. Third, the formation of WSOC will increase the hygroscopicity of aerosols, which in turn results in an increase of $\mathrm{SO}_{2}$ oxidation by increasing the aqueous phase. Therefore, hydroperoxides serve as an important link between sulfate and organic aerosols. Such a link needs further study and should be considered in current atmospheric models.

\section{Conclusions}

Atmospheric $\mathrm{H}_{2} \mathrm{O}_{2}$ and organic hydroperoxides were measured for 13 days during the PRIDE-PRD'06 campaign at Backgarden, a rural site located $\sim 60 \mathrm{~km}$ northwest of Guangzhou. $\mathrm{H}_{2} \mathrm{O}_{2}$ and MHP were the dominant hydroperoxides present in the air with a maximum mixing ratio of $4.6 \mathrm{ppbv}$ for $\mathrm{H}_{2} \mathrm{O}_{2}$ and $0.8 \mathrm{ppbv}$ for MHP. BHMP, PAA, HMHP, 1-HEHP and EHP were detected occasionally. $\mathrm{H}_{2} \mathrm{O}_{2}$ exhibited the maximum mixing ratio mainly between 12:00 and 18:00 LT on sunny days and low values at night and in the morning. Sometimes a second peak was observed during the evening (20:00-02:00 LT), which might be produced by the ozonolysis of alkenes. The diurnal variation of MHP was generally consistent with that of $\mathrm{H}_{2} \mathrm{O}_{2}$ but less pronounced. The estimation for the $\mathrm{H}_{2} \mathrm{O}_{2}$ formation rate from $\mathrm{HO}_{2}$ recombination indicates that in the morning most of the $\mathrm{H}_{2} \mathrm{O}_{2}$ was formed through local photochemical activity, and vertical mixing might be a source. It was noteworthy that high levels of hydroperoxides were found in polluted air with a high mixing ratio of VOC and $\mathrm{CO}$. The high level of $\mathrm{HO}_{2}$ radicals and the low level of $\mathrm{NO}$ detected simultaneously in this region in the day may effectively support the production of hydroperoxides. High concentrations of $\mathrm{H}_{2} \mathrm{O}_{2}$ and MHP were detected in samples of rain collected during a shower when a strong typhoon passed through the observation site. The estimation using the Henry's Law indicates that a considerably high mixing ratio of MHP resided above the boundary layer and might further influence the redistribution of $\mathrm{HO}_{\mathrm{x}}$ and $\mathrm{RO}_{\mathrm{x}}$ radicals in the PRD region. Evidence was found that hydroperoxides, in particular $\mathrm{H}_{2} \mathrm{O}_{2}$, contributed considerably to the formation of aerosol-phase sulfate via the aqueous-phase oxidation, and heterogeneous reactions may contribute substantially to the concentration of sulfate measured at the site. Furthermore, the results seem to imply that hydroperoxides may contribute potentially to the formation of WSOC, as indicated by the fact that their diur- nal variations exhibited a negative correlation. This possibly provides evidence gathered in the field to support the importance of hydroperoxides in the formation of SOA found in laboratory studies. We suggest that hydroperoxides serve as an important link between sulfate and organic aerosols. This link needs further study and should be considered in current atmospheric models.

Acknowledgements. The authors gratefully thank the National Natural Science Foundation of China (grants 20677002 and 20107001), and the Project of Development Plan of the State Key Fundamental Research of MOST of China (grant 2002CB410801), for their financial support. The authors would like to thank F. Yang, $\mathrm{S}$. Guo, and $\mathrm{X}$. Li for their $\mathrm{O}_{3}, \mathrm{SO}_{2}, \mathrm{CO}$ and $\mathrm{PM}_{2.5}$ measurements and data support (Peking University); H. Su for gas-phase $\mathrm{HNO}_{3}$ measurement (Peking University); B. Wang for PAN measurement (Peking University); S.-J. Fan for meteorological data (Sun yet-sen University); and C.-H. Lai for VOC measurement (Research Center of Environment Changes, Academia Sinica, Taiwan).

Edited by: L. Carpenter

\section{References}

Ammann, M. and Pöschl, U.: Kinetic model framework for aerosol and cloud surface chemistry and gas-particle interactions - Part 2: exemplary practical applications and numerical simulations, Atmos. Chem. Phys., 7, 6025-6045, 2007, http://www.atmos-chem-phys.net/7/6025/2007/.

Andreae, M. O. and Crutzen, P. J.: Atmospheric aerosols: biogeochemical sources and role in atmospheric chemistry, Science, 276, 1052-1058, 1997.

Arellanes, C., Paulson, S. E., Fine, P. M., and Sioutas, C.: Exceeding of Henry's law by hydrogen peroxide associated with urban aerosols, Environ. Sci. Technol., 40, 4859-4866, 2006.

Atkinson, R. and Aschmann, S. M.: OH production from the gasphase reactions of $\mathrm{O}_{3}$ with a series of alkenes under atmospheric conditions, Environ. Sci. Technol., 27(7), 1357-1363, 1993.

Atkinson, R.: Gas-phase tropospheric chemistry of organic compounds, J. Phys. Chem. Ref., Data, Monogr., 2, 1-216, 1994.

Becker, K. -H., Bechara, J., and Brockmann, K. J.: Studies on the formation of $\mathrm{H}_{2} \mathrm{O}_{2}$ in the ozonolysis of alkenes, Atmos. Environ., Part A, 27, 57-61, 1993.

Becker, K. -H., Brockmann, K. J., and Bechara, J.: Production of hydrogen peroxide in forest air by reaction of ozone with terpenes, Nature, 346, 256-258, 1990.

Böge, O., Miao, Y., Plewka, A., and Herrmann, H.: Formation of secondary organic particulate phase compounds from isoprene gas-phase oxidation products: an aerosol chamber and field study, Atmos. Environ., 40, 2501-2509, 2006.

Buffalini, J. J., Gay, B. W., and Brubaker, K. L.: Hydrogen peroxide formation from formaldehyde photooxidation and its presence in urban atmospheres, Environ. Sci. Technol., 6, 616-622, 1972.

Calvert, J. G., Lazrus, A. L., Kok, G. L., Heikes, B. G., Welega, J. G., Lind, J., and Cantrell, C. A.: Chemical mechanism of acid generation in the troposphere, Nature, 317, 27-35, 1985.

Chen, Z. M., Wang, H. L., Zhu, L. H., Wang, C. X., Jie, C. Y., and Hua, W.: Aqueous-phase ozonolysis of methacrolein and methyl 
vinyl ketone: a potentially important source of atmospheric aqueous oxidants, Atmos. Chem. Phys., 8, 2255-2265, 2008, http://www.atmos-chem-phys.net/8/2255/2008/.

Chin, M., Jacob, D. J., Munger, J. W., Parrish, D. D., and Doddridge, B. G.: Relationship of ozone and carbon monoxide over North America, J. Geophys. Res., 99, 14 565-14 573, 1994.

Chung, M. Y., Muthana, S., Paluyo, R. N., and Hasson, A. S.: Measurements of effective Henry's law constants for hydrogen peroxide in concentrated salt solutions, 39, 2981-2989, 2005.

Claeys, M., Graham, B., Vas, G., Wang, W., Vermeylen, R., Pashynska, V., Cafmeyer, J., Guyon, P., Andreae, M.O., Artaxo, P., and Maenhaut, W.: Formation of secondary organic aerosols through photooxidation of isoprene, Science, 303, 1173-1176, 2004a.

Claeys, M., Wang, W., Ion, A. C., Kourtchev, I., Gelencsér, A., and Maenhaut, W.: Formation of secondary organic aerosols from isoprene and its gas-phase oxidation products through reaction with hydrogen peroxide, Atmos. Environ., 38, 4093-4098, 2004b.

Cohan, D. S., Schultz, M. G., Jacob, D. J., Heikes, B. G., and Blake, D. R.: Convective injection and photochemical decay of peroxides in the upper troposphere: methyl iodide as a tracer of marine convection, J. Geophys. Res., 104(D5), 5717-5724, 1999.

Das, M. and Aneja, V. P.: Measurements and analysis of concentrations of gaseous hydrogen peroxide and related species in the rural central Piedmont region of North Carolina, Atmos. Environ., 28, 2473-2483, 1994.

Facchini, M. C., Fuzzi, S., Lind, J. A., Fierlingeroberlinninger, H., Kalina, M., Puxbaum, H., Winiwarter, W., Arends, B. G., Wobrock, W., Jaeschke, W., Berner, A., and Kruisz, C.: Phase-partitioning and chemical-reactions of lowmolecularweight organic-compounds in fog, Tellus, 44, 533-544, 1992.

Fels, M. and Junkermann, W.: The occurrence of organic peroxides in air at mountain site, Geophys. Res. Lett., 21, 341-344, 1994.

Finlayson-Pitts, B. J. and Pitts, J. N.: Atmospheric Chemistry: Fundamentals and Experimental Techniques, Wiley Interscience, John Wiley and Sons, New York, 1986.

François, S., Sowka, I., Monod, A., Temime-Roussel, B., Laugier, J. M., and Wortham, H.: Development of an online analyzer of atmospheric $\mathrm{H}_{2} \mathrm{O}_{2}$ and several organic hydroperoxides for field campaigns, Atmos. Res., 74, 525-545, 2005.

Fung, C. S., Misra, P. K., Bloxam, R., and Wong, S.: A numerical experiment on the relative importance of $\mathrm{H}_{2} \mathrm{O}_{2}$ and $\mathrm{O}_{3}$ in aqueous conversion of $\mathrm{SO}_{2}$ to $\mathrm{SO}_{4}^{2-}$, Atmos. Environ., $25 \mathrm{~A}(2)$, 411-423, 1991.

Gäb, S., Hellpointner, E., Turner, W. V., and Korte, F.: Hydroxymethyl hydroperoxide and bis(hydroxymethyl) peroxide from gas-phase ozonolysis of naturally occurring alkenes, Nature, 316 , 535-536, 1985.

Gäb, S., Turner, W. V., Wolff, S., Becker, K. H., Ruppert, L., and Brockmann, K. J.: Formation of alkyl and hydroxyalkyl hydroperoxides in ozonolysis in water and in air, Atmos. Environ., 29, 2401-2407, 1995.

Grossmann, D., Moortgat, G. K., Kibler, M., Kibler, M., Schlomski, S., Bachmann, K., Alicke, B., Geyer, A., Platt, U., Hammer, M. U., Vogel, B., Mihelcic, D., Hofzumahaus, A., Holland, F., and Volz-Thomas, A.: Hydrogen peroxide, organic peroxides, carbonyl compounds, and organic acids measured at Pabstthum during BERLIOZ, J. Geophys. Res., 108(D4), 8250, doi:10.1029/2001JD001096, 2003.
Gunz, D. W. and Hoffmann, M. R.: Atmospheric chemistry of peroxides: a review, Atmos. Environ., 24, 1601-1633, 1990.

Hasson, A. S. and Paulson, S. E.: An investigation of the relationship between gas-phase and aerosol-borne hydroperoxides in urban air, J. Aerosol. Sci., 34, 459-468, 2003.

Hatakeyama, S. and Akimoto, H.: Reactions of criegee intermediates in the gas phase, Res. Chem. Intermed., 20, 503-524, 1994.

Heikes, B. G., Lee, M., Bradshaw, J., Sandholm, S., Davis, D. D., Chameides, W., Rodriguez, H., Liu, S., and McKeen, S.: Hydrogen peroxide and methyl hydroperoxide distributions over the North Pacific in the fall of 1991, J. Geophys. Res., 101, 18911905, 1996.

Hellpointner, E. and Gäb, S.: Detection of methyl, hydroxymethyl and hydroxyethyl hydroperoxides in air and precipitation, Nature, 337, 631-634, 1989.

Hewitt, C. N. and Kok, G. L.: Formation and occurrence of organic hydroperoxides in the troposphere: Laboratory and field observations, J. Atmos. Chem., 12, 181-194, 1991.

Hoffmann, M. R. and Edwards, J. O.: Kinetics of oxidation of sulfite by hydrogen-peroxide in acidic solution, J. Phys. Chem., 79, 2096-2098, 1975.

Holland, F., Hofzumahaus, A., Schaefer, J., Kraus, A., and Paetz, H. -W.: Measurements of $\mathrm{OH}$ and $\mathrm{HO}_{2}$ radical concentrations and photolysis frequencies during BERLIOZ, J. Geophys. Res., 108(D4), 8246, doi:10.1029/2001JD001393, 2003.

Horie, O., Neeb, P., Limbach, S., and Moortgat, G. K.: Formation of formic acid and organic peroxides in the ozonolysis of ethene with added water vapour, Geophys. Res. Lett., 21, 1523-1526, 1994.

Iinuma, Y., Böge, O., Gnauk, T., and Herrmann, H.: Aerosolchamber study of the $\alpha$-pinene/ $\mathrm{O}_{3}$ reaction: influence of particle acidity on aerosol yields and products, Atmos. Environ., 38, 761-773, 2004.

Jackson, A. V. and Hewitt, C. N.: Hydrogen peroxide and organic hydroperoxide mixing ratios in air in a eucalyptus forest in central Portugal, Atmos. Environ., 30, 819-830, 1996.

Jacob, D. J., Heikes, B. G., Fan, S. -M., Logan, J. A., Mauzerall, D. L., Bradshaw, J. D., Singh, H. B., Gregory, G. L., Talbot, R. W., Blake, D. R., and Sachse, G. W.: The origin of ozone and $\mathrm{NO}_{\mathrm{x}}$ in the tropical troposphere: A photochemical analysis of aircraft observations over the south Atlantic basin, J. Geophys. Res., 101, 24 235-24 250, 1996.

Jacob, P., Tavares, T. M., Rocha, V. C., and Klockow, D.: Atmospheric $\mathrm{H}_{2} \mathrm{O}_{2}$ field-measurements in a tropical environmentBahia, Brazil, Atmos. Environ., 124A, 377-382, 1990.

Jaeglé, L., Jacob, D. J., Wennberg, P. O., Spivakovsky, C. M., Hanisco, T. F., Lanzendorf, E. J., Hintsa, E. J., Fahey, D. W., Keim, E. R., Proffitt, M. H., Atlas, E. L., Flocke, F., Schauffler, S., McElroy, C. T., Midwinter, C., Pfister, L., and Wilson, J. C.: Observed $\mathrm{OH}$ and $\mathrm{HO}_{2}$ in the upper troposphere suggest a major source from convective injection of peroxides, 24, 3181-3184, 1997.

Jang, M. S., Carroll, B., Chandramouli, B., and Kamens, R. M.: Particle growth by acid-catalyzed heterogeneous reactions of organic carbonyls on preexisting aerosols, Environ. Sci. Technol., 37, 3828-3837, 2003.

Jang, M. S., Czoschke, N. M., Lee, S., and Kamens, R. M.: Heterogeneous atmospheric aerosol production by acid-catalyzed particle-phase reactions, Science, 298, 814-817, 2002. 
Jayne, J. T. and Davidovits, P.: Uptake of $\mathrm{SO}_{2}(\mathrm{~g})$ by aqueous surfaces as a function of $\mathrm{pH}$ : the effect of chemical reaction at the interface, J. Phys. Chem., 94, 6041-6048, 1990.

Johnson, R. M. and Siddiqi, I. W.: The determination of organic peroxides, Pergamon, New York, 119 pp., 1970.

Kelly, T. J., Daum, P. H., and Schwartz, S. E.: Measurements of peroxides in cloudwater and rain, J. Geophys. Res., 90, 78617871, 1985.

Kim, Y. M., Lee, M., Chang, W., Lee, G., Kim, K. R., and Kato, S.: Atmospheric peroxides over the North Pacific during IOC 2002 shipboard experiment, Chemosphere, 69, 1638-1646, 2007.

Klippel, W. and Warneck, P.: Formaldehyde in rain water and on atmospheric aerosol, Geophys. Res. Lett., 5, 177-179, 1978.

Kok, G. L., McLaren, S. E., and Staffelbach, T. A.: HPLC determination of atmospheric organic hydroperoxides, J. Atmos. Ocean. Tech., 12, 282-289, 1995.

Kroll, J. H., Ng, N. L., Murphy, S. M., Flagan, R. C., and Seinfeld, J. H.: Secondary organic aerosol formation from isoprene photooxidation, Environ. Sci. Technol., 40, 1869-1877, 2006.

Kurth, H.-H., Gäb, S., Turner, W. V., and Kettrup, A.: A highperformance liquid chromatography system with an immobilized enzyme reactor for detection of hydrophilic organic peroxides, Anal. Chem., 63, 2586-2589, 1991.

Lazrus, A. L., Kok, G. L., Lind, J. A., Gitlin, S. N., Heikes, B. G., and Shetter, R. E.: Automated fluorimetric method for hydrogen peroxide in air, Anal. Chem., 58, 594-597, 1986.

Lee, J. H., Leahy, D. F., Tang, I. N., and Newman, L.: Measurement and speciation of gas phase peroxides in the atmosphere, $\mathrm{J}$. Geophys. Res., 98, 5122-5130, 1993.

Lee, M., Heikes, B. G., and Jacob, D. J.: Enhancements of hydroperoxides and formaldehyde in biomass burning impacted air and their effect on atmospheric oxidant cycles, J. Geophys. Res., 103(D11), 13 201-13 212, 1998.

Lee, M., Heikes, B. G., and O'Sullivan, D.: Hydrogen peroxide and organic hydroperoxide in the troposphere: A review, Atmos. Environ., 34, 3475-3494, 2000.

Lee, M., Kim, J.-A., Kim, Y.-M., and Lee, G.: Characteristics of atmospheric hydrogen peroxide variations in Seoul megacity during 2002-2004, Sci. Total. Environ., 393, 299-308, 2008.

Lee, M., Noone, B. C., O'Sullivan, D., and Heikes, B. G.: Method for the collection and HPLC analysis of hydrogen peroxide and $\mathrm{C}_{1}$ and $\mathrm{C}_{2}$ hydroperoxides in the atmosphere, J. Atmos. Ocean. Technol., 12, 1060-1070, 1995.

Li, G. Y., Tang, X. L., BI, X. H., Yi, F., Sheng, G. Y., and Fu, J. M.: Composition and mutagenicity of particle sized fraction from urban particulate matter in Guangzhou City, Acta Scientiae Circumstantiae, 25(3), 319-323, 2005.

Li, L., Chen, Z. M., Zhang, Y. H., Zhu, T., Li, J. L., and Ding, J.: Kinetics and mechanism of heterogeneous oxidation of sulfur dioxide by ozone on surface of calcium carbonate, Atmos. Chem. Phys., 6, 2453-2464, 2006, http://www.atmos-chem-phys.net/6/2453/2006/.

Li, L., Chen, Z. M., Zhang, Y. H., Zhu, T., Li, S., Li, H. J., Zhu, L. H., and $\mathrm{Xu}, \mathrm{B}$. Y.: Heterogeneous oxidation of sulfur dioxide by ozone on the surface of sodium chloride and its mixtures with other components, J. Geophys. Res., 112, D18301, doi:10.1029/2006JD008207, 2007.

Li, S., Chen, Z. M., and Shi, F.: Determination of Henry's Law constant for methyl hydroperoxide by long path FTIR, Prog. Nat.
Sci., 14(8), 31-35, 2004.

Li, Y. S., Campana, M., Reimann, S., Schaub, D., Stemmler, K., Staehelin, J., and Peter, T.: Hydrocarbon concentrations at the Alpine mountain sites Jungfraujoch and Arosa, Atmos. Environ., 39, 1113-1127, 2005.

Lightfoot, P. D., Cox, R. A., Crowley, J. N., Destriau, M., Hayman, G.. D., Jenkin, M. E., Moortgat, G. K., and Zabel, F.: Organic peroxy radicals: kinetics, spectroscopy and tropospheric chemistry, Atmos. Environ., 26(10), 1805-1961, 1992.

Lind, J. A. and Kok, G. L.: Correction to 'Henry's Law determination for aqueous solutions of hydrogen peroxide, methyl hydroperoxide and peroxyacetic acid', J. Geophys. Res., 99, 21 119-21 119, 1994.

Lind, J. A. and Kok, G. L.: Henry's Law determination for aqueous solutions of hydrogen peroxide, methyl hydroperoxide and peroxyacetic acid, J. Geophys. Res., 91, 7889-7895, 1986.

Lind, J. A., Lazrus, A. L., and Kok, G. L.: Aqueous phase oxidation of sulfur (IV) by hydrogen peroxide and methyl hydroperoxide and peroxyacetic acid, J. Geophys. Res., 92, 4171-4177, 1987.

Lohmann, U. and Feichter, J.: Global indirect aerosol effects: a review, Atmos. Chem. Phys., 5, 715-737, 2005,

Madronich, S. and Calvert, J. G.: Permutation reactions of organic peroxy radicals in the troposphere, J. Geophys. Res., 95(D5), 5697-5715, 1990.

Mair, R. D. and Hall, R. T.: Determination of organic peroxides by physical, chemical, and colorimetric methods, Organic Peroxides Vol. 2, edited by: Swern, D., Wiley-Interscience, 535-635, 1970.

Mari, C., Jacob, D. J., and Bechthold, P.: Transport and scavenging of soluble gases in a deep convective cloud, J. Geophys. Res., 105(D17), 22 255-22 267, 2000.

Miyazaki, Y., Kondo, Y., Takegawa, N., Komazaki, Y., Fukuda, M., Kawamura, K., Mochida, M., Okuzawa, K., and Weber, R. J.: Time-resolved measurements of water-soluble organic carbon in Tokyo, J. Geophys. Res., 111, D23206, doi:10.1029/2006JD007125, 2006.

Moortgat, G. K., Grossmann, D., Boddenberg, A., Dallmann, G., Ligon, A. P., Turner, W. V., Gäb, S., Slemr, F., Wieprecht, W., Acker, K., Kibler, M., Schlomski, S., and Bächmann, K.: Hydrogen peroxide, organic peroxide and carbonyl compounds determined during the BERLIOZ Campaign, J. Atmos. Chem., 42, 443-463, 2002.

Morgan, R. B. and Jackson, A. V.: Measurements of gas-phase hydrogen peroxide and methyl hydroperoxide in the coastal environment during the PARFORCE project, J. Geophys. Res.Atmos., 107, 8109, doi:10.1029/2000JD000257, 2002.

Neeb, P., Sauer, F., Horie, O., and Moortgat, G. K.: Formation of hydroxymethyl hydroperoxide and formic acid in alkene ozonolysis in the presence of water vapour, Atmos. Environ., 31, 1417$1423,1997$.

Novakov, T. and Penner, J. E.: Large contribution of organic aerosols to cloud-condensation-nuclei concentrations, Nature, 365, 823-826, 1993.

O’Sullivan, D. W., Heikes, B. G., Lee, M., Chang, C., Gregory, G., Blake, D., and Sachase, G.: The distribution of hydrogen peroxide and methyl hydroperoxide in the Pacific and South Atlantic, J. Geophys. Res., 104, 5635-5646, 1999.

O'Sullivan, D. W., Lee, M. Y., Noone, B. C., and Heikes, B. G.: Henry's law constant determinations for hydrogen peroxide, methyl hydroperoxide, hydroxymethyl hydroperoxide, ethyl 
hydroperoxide, and peroxyacetic acid, J. Phys. Chem., 100(8), 3241-3247, 1996.

Paulson, S. E. and Orlando, J. J.: The reactions of ozone with alkenes: An important source of HOx in the boundary layer, Geophys. Res. Lett., 23, 3727-3730, 1996.

Pena, R. M., Garcia, S., Herrero, C., and Lucas, T.: Measurements and analysis of hydrogen peroxide rainwater levels in a Northwest region of Spain, Atmos. Environ., 35, 209-219, 2001.

Penkett, S. A., Jones, B. M. R., Brice, K. A., and Eggleton, A. E. J.: The importance of atmospheric ozone and hydrogen peroxide in oxidising sulphur dioxide in cloud and rainwater, Atmos. Environ., 13, 123-137, 1979.

Penner, J. E., Andreae, M., Annegarn, H., Barrie, L., Feichter, J., Hegg, D., Jayaraman, A., Leaitch, R., Murphy, D., Nganga, J., and Pitari, G.: Climate Change 2001: the Scientific Basis. Contribution of Working Group I to the Third Assessment Report of the Intergovernmental Panel on Climate Change, Cambridge University Press, 289-348, 2001.

Perry, K. D., Cahill, T. A., Schnell, R. C., and Harris, J. M.: Long-Range Transport of Anthropogenic Aerosols to the National Oceanic and Atmospheric Administration Baseline Station at Mauna Loa Observatory, Hawaii, J. Geophys. Res., 104(D15), 18 521-18 535, 1999.

Pöschl, U., Rudich, Y., and Ammann, M.: Kinetic model framework for aerosol and cloud surface chemistry and gas-particle interactions - Part 1: General equations, parameters, and terminology, Atmos. Chem. Phys., 7, 5989-6023, 2007, http://www.atmos-chem-phys.net/7/5989/2007/.

Ravetta, F., Jacob, D. J., Brune, W. H., Heikes, B. G., Anderson, B. E., Blake, D. R., Gregory, G. L., Sachse, G. W., Sandholm, S. T., Shetter, R. E., Singh, H. B., and Talbot, R. W.: Experimental evidence for the importance of convected methylhydroperoxide as a source of hydrogen oxide $\left(\mathrm{HO}_{\mathrm{x}}\right)$ radicals in the tropical upper troposphere, J. Geophys. Res., 106(D23), 32 709-32 716, 2001.

Ravishankara, A. R.: Heterogeneous and Multiphase Chemistry in the Troposphere, Science, 276, 1058-1065, doi:10.1126/science. 276.5315.1058, 1997.

Reeves, C. E. and Penkett, S. A.: Measurements of peroxides and what they tell us, Chem. Rev., 103, 5199-5218, 2003.

Rieche, A. and Hitz, F.: Uber monomethyl-hydroperoxide, Ber. Dtsch. Chem. Ges., 62, 2458-2472, 1929.

Rieche, A. and Meister: Uber peroxyde des formaldehyde: oxymethylhydroperoxyd, Ber. Dtsch. Chem. Ges., 68, 14681472, 1935.

Sander, S. P., Friedl, R. R., Ravishankara, A. R., Golden, D. M., Kolb, C. E., Kurylo, M. J., Huie, R. E., Orkin, V. L., Molina, M. J., Moortgat, G. K., and Finlayson-Pitts, B. J.: Chemical Kinetics and Photochemical Data for Use in Atmospheric Studies, JPL Publication 02-25, Evaluation No. 14, 5-35, 2003.

Sauer, F., Beck, J., Schustera, G., and Moortgat, G. K.: Hydrogen peroxide, organic peroxides and organic acids in a forested area during FIELDVOC'94, Chemosphere, Global Change Sci., 3, 309-326, 2001.

Sauer, F., Limbach, S., and Moortgat, G. K.: Measurements of hydrogen peroxide and individual organic peroxides in the marine troposphere, Atmos. Environ., 31, 1173-1184, 1997.

Sauer, F., Schäfer, C., Neeb, P., Horie, O., and Moortgat, G. K.: Formation of hydrogen peroxide in the ozonolysis of simple alkenes under humid conditions, Atmos. Environ., 33, 229-241, 1999.
Sauer, F., Schuster, G., Schäfer, C., and Moortgat, G. K.: Determination of $\mathrm{H}_{2} \mathrm{O}_{2}$ and organic peroxides in cloud- and rain-water on the Kleiner Feldberg during FELDEX, Geophys. Res. Lett., 23, 2605-2608, 1996.

Saxena, P. and Hildemann, L.M.: Water-soluble organics in atmospheric particles: a critical review of the literature and application of thermodynamics to identify candidate compounds, J. Atmos. Chem., 24, 57-109, 1996.

Schwartz, S. E.: Gas- and aqueous-phase chemistry of $\mathrm{HO}_{2}$ in liquid water clouds, J. Geophys. Res., 89, 11 589-11 598, 1984.

Seinfeld, J. H. and Pandis, S. N.: : From Air Pollution to Climate Change, Atmospheric Chemistry and Physics, Wiley, New York, 724-743, 1998.

Seuwen, R., and Warneck, K.: Oxidation of toluene in $\mathrm{NO}_{\mathrm{x}}$ free air: Product distribution and mechanism, Int. J. Chem. Kin., 28, 315-322, 1995.

Staffelbach, T. A., Kok, G. L., Heikes, B. G., McCully, B., Mackay, G. I., Karecki, D.R., and Schiff, H. I.: Comparison of hydroperoxide measurements made during the Mauna Loa Observatory photochemistry experiment 2, J. Geophys. Res., 101, 1472914739, 1996.

Stockwell, W. R.: On the $\mathrm{HO}_{2}+\mathrm{HO}_{2}$ reaction: Its misapplication in atmospheric chemistry models, J. Geophys. Res., 100, 11 695$11698,1995$.

Su, F., Calvert, J. G., and Shaw, J. H.: Mechanism of the photooxidation of gaseous formaldehyde, J. Phys. Chem., 83, 3185-3191, 1979.

Takegawa, N., Miyazaki, Y., Kondo, Y., Komazaki, Y., Miyakawa, T., Jimenez, J. L., Jayne, J. T., Worsnop, D. R., Allan, J., and Weber, R. J.: Characterization of an Aerodyne Aerosol Mass Spectrometer (AMS): Intercomparison with other aerosol instruments, Aerosol Sci. Technol., 39, 760-770, 2005.

Takegawa, N., Miyakawa, T., Kondo, Y., Jimenez, J. L., Zhang, Q., Worsnop, D. R., and Fukuda, M.: Seasonal and diurnal variations of submicron organic aerosol in Tokyo observed using the Aerodyne aerosol mass spectrometer, J. Geophys. Res., 111, D11206, doi:10.1029/2005JD006515, 2006.

Thompson, A. M.: The Oxidizing Capacity of the Earth's Atmosphere: Probable Past and Future Changes, Science, 256(5060), 1157-1165, 1992.

U.S. Environmental Protection Agency: National Air Quality and Emissions Trends Report, 1999, p. 237, US Environmental Protection Agency, Office of Air Quality Planning and Standards, Research Triangle Park, NC, 2001.

Vácha, R., Slavícek, P., Mucha, M., Finlayson-Pitts, B. J., and Jungwirth, P.: Adsorption of Atmospherically Relevant Gases at the Air/Water Interface: Free Energy Profiles of Aqueous Solvation of $\mathrm{N}_{2}, \mathrm{O}_{2}, \mathrm{O}_{3}, \mathrm{OH}, \mathrm{H}_{2} \mathrm{O}, \mathrm{HO}_{2}$, and $\mathrm{H}_{2} \mathrm{O}_{2}$, J. Phys. Chem., 108, 11 573-11 579, 2004.

Valverde-Canossa, J., Grossmann, D., Neeb, P., and Moortgat, G. $\mathrm{K}$.: Ozonolysis of biogenic and anthropogenic alkenes as a relevant source of tropospheric $\mathrm{H}_{2} \mathrm{O}_{2}$ and organic hydroperoxides, in: Proceedings of the Eurotrac-2 Symposium 2000 on "Transport and Chemical Transformation in the Troposphere", 2731 March 2000, Garmisch-Partenkirchen, Germany, edited by: Midgley, P. M., Reuther, M., and Williams, M., Springer-Verlag, New York, (extended abstract on CD-ROM), 2001.

Valverde-Canossa, J.: Sources and sinks of organic peroxides in the planetary boundary layer, Ph.D. Dissertation, Johannes 
Gutenberg-Univ., Mainz, 2004.

Walcek, C. J.: A theoretical estimate of $\mathrm{O}_{3}$ and $\mathrm{H}_{2} \mathrm{O}_{2}$ dry deposition over Northeastern United States, Atmos. Environ., 21, 26492659, 1987.

Walker, S. J., Evans, M. J., Jackson, A. V., Steinbacher, M., Zellweger, C., and McQuaid, J. B.: Processes controlling the concentration of hydroperoxides at Jungfraujoch Observatory, Switerland, Atmos. Chem. Phys., 6, 5525-5536, 2006, http://www.atmos-chem-phys.net/6/5525/2006/.

Wang, C. X. and Chen, Z. M.: Effect of $\mathrm{CH}_{3} \mathrm{OOH}$ on the atmospheric concentration of $\mathrm{OH}$ radicals, Prog. Nat. Sci., 16 (11), 1141-1149, 2006.

Wang, J. L., Din, G. Z., and Chan, C. C.: Validation of a laboratoryconstructed automated gas chromatograph for the measurement of ozone precursors through comparison with a commercial analogy. J. Chromatogr. A, 1027(1-2), 11-18, 2004

Wang, T., Poon, C. N., Kwok, Y. H., and Li, Y. S.: Characterizing the temporal variability and emission patterns of pollution plumes in the Pearl River Delta of China, Atmos. Environ., 37(25), 3539-3550, 2003.

Watkins, B. A., Parrish, D. D., Buhr, S., Norton, R. B., Trainer, M., Yee, J. E., and Fehsenfeld, F. C.: Factors influencing the mixing ratio of gas phase hydrogen peroxide during the summer at Kinterbish, Alabama, J. Geophys. Res., 100, 22 841-22 851, 1995a.
Watkins, B. A., Parrish, D. D., Trainer, M., Norton, R. B., Yee, J. E., Fehsenfeld, F. C., and Heikes, B.G.: Factors influencing the mixing ratio of gas phase hydrogen peroxide during the summer at Niwot Ridge, Colorado, J. Geophys. Res., 100, 22 831-22 840 , 1995b.

Wennberg, P. O., Hanisco, T. F., Jaegle, L., Jacob, D. J., Hintsa, E. J., Lanzendorf, E. J., Anderson, J. G., Gao, R. S., Keim, E. R., Donnelly, S. G., Del Negro, L. A., Fahey, D. W., McKeen, S. A., Salawitch, R. J., Webster, C. R., May, R. D., Herman, R. L., Proffitt, M. H., Margitan, J. J., Atlas, E. L., Schauffler, S. M., Flocke, F., McElroy, C. T., and Bui, T. P.: Hydrogen radicals, nitrogen radicals, and the production of $\mathrm{O}_{3}$ in the upper troposphere, Science, 279(5347), 49-53, 1998

Wesley, M. L.: Parameterization of surface resistances to gaseous dry deposition in regional scale numerical models, Atmos. Environ., 23, 1293-1304, 1989.

$\mathrm{Xu}$, J. R. and Chen, Z. M.: Determination of peroxides in environmental samples by high performance liquid chromatography with fluorescence detection, Chinese J. Chromatogr., 23, 366369, 2005.

Zhang, Y. H., Shao, K. S., and Tang, X. Y.: The study of urban photochemical smog pollution in China, Acta Scientiarum Natrualium, Universitatis Pekinenesis, 24(2-3), 392-400, 1998.

Zhou, X. L. and Lee, Y.-N.: Aqueous solubility and reaction kinetics of hydroxymethyl hydroperoxide, J. Phys. Chem., 96, 265272, 1992. 